\title{
GEOLOGY, PETROGRAPHY, GEOCHEMISTRY ANDSUITABILITY OF ABU SHEIH PEGMATITE FOR CERAMIC INDUSTRY \\ AHMED EL-MEZAIN ${ }^{(1)}$, SAYEDAHMED MOHAMED OMAR(2), MOHEY EL-DIENABD EL- HAMED \\ AND ABD EL-FATTAHABD EL-MONEEMKABEL ${ }^{(3)}$
}

Al-Azhar University Nuclear Materials Authority Ceramica Cleopatra Company

\begin{abstract}
:
The geological, petrographical and geochemical studies as well as physical properties of Abu Sheih pegmatites and its effects on various types of fired ceramic bodies. The rock units in the study area are classified as follow: Wadi deposits (youngest), Post granitic dikes, pegmatite pockets and veins, syenogranites andgranodiorites (oldest).Thegranodiorites are light grey in colour and medium to coarse grained equigranular rocks, composed of plagioclases, quartz, perthites, hornblendebiotite, and muscovite as essential minerals. Zircon, iron oxides, apatite and titanite are accessory minerals whereas epidote as secondary minerals. But syenogranites show distinct pink to red colours. They are medium to coarse grained, hypidiomorphic, possessing subhedral to euhedral crystal faces, they are composed mainly of perthites, quartz, plagioclase, biotite and muscovite as essential minerals, while zircon, titanite, iron oxides and apatite are the accessory minerals. Epidote and chlorite are present as secondary minerals. The geochemical studies revealed that, the studied Granodiorites were originated from metaluminouscalcalkaline magma intruded in a crust of a thickness less than $30 \mathrm{~km}$ at water pressure less than $2 \mathrm{~kb}$. They could be considered as volcanic arc or continental arc granitoides. The Syenogranites were derived from sialic crust and considered as I-type granites, that originated from peraluminous, calc-alkaline, highly fractionated magma. They could be considered as late orogenic granites, intruded in a crust ranging in thickness from $20 \mathrm{~km}$ to $30 \mathrm{~km}$.

Pegmatites are relatively enriched in Al2O3and $\mathrm{K} 2 \mathrm{O}$ than their granitic host. This is consistent with the mineral composition of pegmatites where they are more enriched in $K$-feldspar and quartz. Also the depletion of $S r$ in pegmatites than their granite host is related to less abundant plagioclase in pegmatites. The geochemical studies revealed thatthe studied pegmatite samples classified as granite,subalkaline nature field, intruded in a crust ranging in thickness from 20 to $30 \mathrm{~km}$.

Keywords: Granodiorites, Syenogranites, Pegmatites, Ceramic Industry
\end{abstract}

\section{INTRODUCTION}

Wadi Abu Sheih area, located between Latitudes $26^{\circ} 30^{\prime}$ and $26^{\circ} 44^{\prime} \mathrm{N}$ and Longitudes $33^{\circ} 20^{\prime}$ and $33^{\circ} 30^{\prime} \mathrm{E}$, North Eastern Desert of Egypt(Fig. 1).It can be accessed through QenaSafaga high road which is running at its southeastern part at sign $\mathrm{Km} 85$ from Qena City to sign $\mathrm{Km} 50$ from Safaga City. The studied area has a special economic importance due to presence of quarrying of feldspars and feldspar sand. Special emphasis was taken for the ability of the studied placer feldspars for ceramic industry in Egypt. The area shows mountains extending more or less parallel to the Red Sea Coast including (Gabal El-Urf $988 \mathrm{~m}$ a.s.1.). It is dissected by several wadis (valleys) such as Wadi El-Sheih and Wadi El-Urf.Pegmatites occur as small stock like body invading the surrounded granodioritesandsyenogranites. They composed mainly of K-feldspar, micaand quartz present in the core.

\section{Previous Works}

The previous works carried out on Wadi Abu El-Sheih area and its surroundings are reviewed briefly in the following paragraphs:

El-Shazly et al.,(1982) concluded that, the mafic dikes in Wadi Abu Zawal area are mainly of doleritic and andesitic types. They also suggested that these dikes are related to the volcanicity that took place during Paleozoic and Mesozoic ages and their emplacement is controlled by fracture system.

Habib(1982) detected numerous bright spectral signatures through the digital processing of the Landsat MSS data using band ratio and color enhancement techniques within the alteration features associated with the mineralized granites in the area between G. El Urf and El Erediya. These signatures reflect numerous hydrothermal alterations and mineralized quartz veins.

Moussa and Abu El leil(1983) discussed and 
analyzed the fault trends of the basement rocks in the northern part of the Eastern Desert using structure maps compiled from space images and published maps. They showed that most well developed faults have NNW and NE trends, which control the localization of the mineralization present in the area.

Soliman(1988) studied the geology of the area around Gabal El-Urf and classified the basement rocks cropping out in this area as granite gneisses, arc ophiolitic fragments (gabbros and metavolcanics), synkinematicgranitoids, postkinematic granites and post-granite dikes.

Sharara et al.,(1990) studied the geology and geochemistry of the island arc association of the area around Gabal El-Urf and revealed that, this association is represented by metavolcanics, metagabbros, synkinematicgranitoids and postkinematic granites.

Bishta(1999) used image processing techniques, airborne gamma-ray spectrometric data, petrological and field investigations for mapping the different rock types in the area between Latitudes $26^{\circ} 15^{\prime}-26^{\circ} 40^{\prime} \mathrm{N}$ and Longitudes $33^{\circ} 15^{`}$ - $33^{\circ} 50^{\prime}$ E. He also identified anomalously high radioactive locations mainly restricted and confined to the late-tectonic younger granite rocks.

Assran(2002) studied the Abu Shihat radioactive prospect area using application of ground magnetic and multi-frequency EM techniques. He detected some surficial local anomalies of shallow depth. These anomalies are of narrow semicircular to circular shapes of relatively high amplitudes having N-S, NW-SE and NE-SW directions. He concluded that these anomalies are mainly associated with a set of felsite dikes, alteration and fault zones. Because of the high radiometric anomalous zones, He recommended to more detailed ground survey and subsequent exploration drilling.

El-Naggar and Abdel-Shafy(2006) studied the granites of Wadi Abu Zawal area. They concluded that, these granites have originated from metaluminous to peraluminouscalc-alkaline magmas with many chemical features similar to I-type granites that developed in volcanic arc tectonic setting in a compressional regime.
Aboelkhair et al.,(2010) used ASTER level $1 \mathrm{~B}$ (radiance at the sensor) TIR-bands and level 2B04 (surface emissivity) data analysis to map and detect four of 14 rare-metal-enriched albite granite, which are classified as I-type magnetiteseries (G3 type) granites in the Central Eastern Desert of Egypt. Band ratios, band ratio combination and band combinations were used to produce a new ASTER false colored composite band ratio combination (b12/b13: b11/b12: b14/ b13) in RGB which is applied successfully for mapping albite granite in the study area. This new combination clearly separated albite granite.

Azab(2011) studied thepetrography, mineralogy and geochemistry of WadiSafaga granites. She classified the rock units in the area into: granodiorite-tonalite, Dokhan volcanic, monzogranites, syenogranites and post-granite dikes and felsite sheets. She also concluded that, the $\mathrm{U}$ and Th distribution was mainly controlled by magmatic process.

Abdelrahman(2014) applied thermal remote sensing imagery for studying uranium mineralization at El-Missikat and El-Eridiya district (south to the study area). He arranged the rock units exposed in the area chronologically (from older to younger) as metavolcanics, older granitoids, younger gabbros, monzogranites (1st phase of Syenogranites), quartz-feldspar porphyry dikes, syenogranites (2nd phase of Syenogranites), mafic dikes and Nubian sandstones. He recommended some new localities for uranium exploration that have similar conditions as the explored sites at northern El-Missikat and southern El-Eridiya.

\section{Methodology}

Detailed field work was carried out through several field trips usingphotomosaics of scale 1:50.000. Landsat ETM data for the study area was processed for geological mapping using the ERDAS imagine 9.1.and Arc GIS 9.3 software programs.

Thirty seven representative thin sections were prepared to identify the different rock types as well as their rock forming minerals and their textural relationships. The petrography was studied 
using a Nikon polarizing microscope equipped with an automatic photomicrography attachment (Micro flex AFX-II).

The chosen samples were jaw-crushed and ground for geochemical analyses. Major oxides were measured using conventional wet chemical techniques of (Shapiro and Brannock 1962)whit some modifications given by (El-Reedy 1985). The X-ray fluorescence technique (XRF), was used to determine some trace element contents using PHILIPS X'Unique-II spectrometer with automatic sample changer PW 1510, (30 positions). This instrument is connected to a computer system using X-40 program for spectrometry.

The radiometric measurements were carried out in the field by using the portable RS230 spectrometer which measure $\mathrm{eU}$ and $\mathrm{eTh}$ in (ppm) and $\mathrm{K}$ in (\%) as well as the total gamma ray intensity emitted from the various rocks in counts per second (c.p.s). A multichannel analyzer gamma ray spectrometer was used to determine the $\mathrm{eU}$, and $\mathrm{eTh}$ concentrations in the laboratory. The system consists of NaI-T1Bicron scintillation detector connected with NE-4658 amplifier and a high voltage power supply with HV digital display.

The physical and chemical tests for pegmatite and feldspars (water absorption percentage, shrinkage and bending strength) were carried out in the Central Laboratories of Ceramica Cleopatra Company.

\section{Geologic Setting}

The study area covers a total exposure surface area of about $400 \mathrm{~km} 2$. Generally, the area is characterized by rugged topography with moderate to high relief. The area comprises different rock types of Precambrian age. A geologic map (Fig. 2) was prepared for the study area with the aid of the aerial photo mosaics, the intensive field geological works and some previous works (El-Tahir, 1978 and Asran, 2002). Accordingly, the rock types in the study area are classified as follow: Wadi deposits (youngest), Post granitic dikes, pegmatite pockets and veins,syenogranites, granodiorites (oldest).

The granodiorites exposed widely along Qena-Safaga road are medium to coarse grained with gray to grayish pink color. They are characterized by exfoliation, cavernous weathering. The Syenogranites are represented by large mass of Gabal El-Urf. They are medium to coarse grained, pink and red colour.

The emplacement of the granite plutons is followed by injection of veins and dikes of different shapes and compositions. They are represented by pegmatite bodies, aplite dikes, felsite dikes, quartz veins and basic dikes. Pegmatites in the study area occur as dikes and vein-like bodies mainly lenticular in shape (Fig. 3) invading the surrounding granites with sharp contact (Fig. 4). Most of these pegmatite bodies are concentrated along NNE-SSW fractures affecting the granites. The dimensions of pegmatite bodies range from few meters to hundreds of meters. Their lengths reach about $40 \mathrm{~m}$ in Syenogranites and more than $150 \mathrm{~m}$ in granodiorites. Most of the pegmatites are mainly composed of intergrowth of milky quartz and reddish pink Kfeldspar (Fig. 5). Also, they are found with mica which is mainly represented by mica (Fig. 6). The unzoned pegmatites are the common type, whereas the zoned pegmatites are present with minor scales (Fig. 7). Iron oxides are abundant either brownish to reddish hematite or as fine magnetite crystals. Some of these pegmatite bodies have radioactive anomalies.

\section{Petrography}

$\begin{array}{ccc}\text { According to the modal } & \text { the } \\ \text { classification(Streckeisen } & \text { 1976), } & \text { quartz, }\end{array}$
plagioclase and potash feldspars were recalculated to $100 \%$ and plotted on QAP diagram. The Granodiorites were plotted in granodiorite field, while the Syenogranites and pegmatites were plotted within the granite field (Fig. 8).

The Granodiorites are represented by granodiorites, which are composed of plagioclase, quartz, perthites, biotite, hornblende and muscovite as essential minerals. Zircon, iron oxides, apatite and titanite are accessory minerals whereas epidote as secondary minerals. The Syenogranites are plotted in the granite fieldand are composed mainly of perthites, quartz, plagioclase, biotite and muscovite as essential minerals, while zircon, titanite, iron oxides and apatite 
are the accessory minerals. Epidote and chlorite are found as secondary minerals.

Pegmatites are composed of alkali feldspar usually microperthitewhich occur as anhedralmegacrysts characterized by fine strings and braided veinlets of albite intergrowths. Twinning, in general, is absent, but it sometimes displays micrographic texture (Fig. 9). Mutual crystal boundaries of alkali feldspar microperthite and quartz are corroded. Alkali feldspar microperthite commonly encloses. Silica liberated as myrmekitic intergrowths with albite rims are restricted in distribution to the contacts between adjacent crystals of $\mathrm{k}$-feldspars.

Quartzoccurs as anhedral crystals strongly invadeing both plagioclase and perthite. It is commonly clear and free of inclusions. It is usually strained exhibiting wavy and undulose extinctions (Fig. 10).

Plagioclase occurs as tabular, anhedral to subhedral, small tabular grains of oligoclase. Plagioclase exhibites only fine lamellar twinning, which is partly obscured by alteration. Zoning is hardly recognized, though it is indirectly perceived as variations in alteration intensity across the central and marginal parts of individual grains (Fig. 11).

Mica is represented by muscovite and biotite (Fig. 12). Biotite is very rare or absent in some samples (Fig. 13).

Titanite is found as irregular crystals usually associated with muscovite and kaolinized feldspars (Fig. 14). Some titanite crystals are included with zircon reflecting the substitution of Ti by Zr.(Read. 1984).

Iron oxides form irregular grains disseminated in feldspars, quartz and muscovite (Figs. 14 and 15). Most of cracks in the feldspars and quartz are filled with iron oxides.

\section{Geochemistry}

The geochemical characters of Abu Sheih pegmatites will be clarified and deduced in terms of major oxides and trace elements data (Table 1). These rocks are used in ceramic in- dustry. Generally the studied pegmatites have the composition of syenogranites and have highpotassiccontents. They are characterized by their high silica contents with an average value of $70 \%$, potash contents with an average value of $7 \%$ lower content of trace element and high contentes of $\mathrm{Rb}$ and $\mathrm{Y}$.

Based on the Or-Ab-An ternary diagram of O'Connor (1965), and modified by Barker (1979), the studied pegmatite samples are plotted in granite field (Fig. 16). The alkali-silica variation diagram of Irvin and Baragar(1971), is used to distinguish between the alkaline and subalkaline nature. The studied pegmatite samples are plotted in the subalkaline nature field (Fig. 17). The relation between $\mathrm{Na} 2 \mathrm{O}$ and $\mathrm{K} 2 \mathrm{O}$ diagram of Hine et al. (1978). The $\mathrm{Rb}$ - Sr variation diagram according to Condie(1973), is constructed to show that, the studied pegmatite was situated at crustal thickness ranging from 20 to 30 km (Fig. 18).

It is worthy to compare between pegmatites and their host rock (Granodiorites and Syenogranites) on the bases of the average content of major oxides and trace elements (Table 2). It is clear that, the investigated pegmatites are relatively more enriched in $\mathrm{A} 12 \mathrm{O} 3$ and $\mathrm{K} 2 \mathrm{O}$ contents than their granite host. This is consistent with the mineral composition of pegmatites, where they are more enriched in K-feldspar and quartz. Also the depletion in Srin pegmatites than their granites host are related to less abundant plagioclases in the studied pegmatites.

\section{Radioactivity}

The average of eU and $\mathrm{eTh}$ in granodiorites is relatively lower than content of $\mathrm{U}$ and $\mathrm{Th}$ in normal granitic rocks (Rogers and Adams 1969), but the average of $U$ and Th content of Syenogranites (Table 4) are relatively higher than the content of $\mathrm{U}$ and $\mathrm{Th}$ in normal granitic rocks (Rogers and Adams 1969). On the other hand, the average of $U$ and $T h$ in pegmatites is lower than $\mathrm{U}$ and Th of world uraniferous pegmatites(Ford 1982),Egyptian uraniferous pegmatites(Table 4) after (Heikal et al., 2001).

\section{Environmental Impacts}


The minimum, maximum and average absorbed $\gamma$ - dose rate (D) values for the studied pegmatites are shown in (Table 3). The absorbed $\gamma$ - dose rate (D) ranged from 2.66 to $44.9 \mathrm{nGyh}$ 1with 13.53 nGyh-1 as an average. These estimated values of absorbed $\gamma$ - dose rate are comparably lower than the world average value 57 nGyh-1(Tzortzis et al., 2003, Abbady et al., 2005). Furthermore, the average values of annual effective dose (Eff Dose) for all the studied pegmatites were also listed. The values obtained varied between 0.02 and $0.31 \mathrm{mSvy}-1$. The mean value found to be less that than $0.48 \mathrm{mSvy}-1$ [recommended by (UNSCEAR 2000) as the worldwide average of the annual effective dose. The radium equivalent activity (Raeq) range from 5.99 to $105.30 \mathrm{~Bq} / \mathrm{Kg}-1$ with an average value of $31.47 \mathrm{~Bq} / \mathrm{Kg}-1$ for the pegmatites. The values radium equivalent activities (Raeq) are lower than the recommended maximum value of $370 \mathrm{~Bq} / \mathrm{kg}-1$ for the studied rocks. The values of external and internal hazard indices (Hex and Hin) for pegmatite,Hex range between 0.02 and 0.28 and Hin range between 0.02 to 0.31 . Average of external and internal hazard indicating that the studied pegmatites can be used as building and interior decorative material of dwelling as well as ceramic industry. The gamma activity index (I $\gamma$ ) used to assess safety requirement for building materials were evaluated and presented in table. The average values of gamma activity index $(\mathrm{I} \gamma)$ for pegmatites are 0.22 . The obtained values of gamma activity indices in the studied rocks were lower dose criterion $(0.3 \mathrm{mSv} / \mathrm{y})$ and corresponds to an activity concentration index of $2 \leq$ I $\gamma \leq 6$ proposed byEC (1999) for materials used in bulk construction.

6. Suitability of Abu Sheih Pegmatite for Ceramic Industry

The final mixture of the ceramic tiles production is generally made up of:

1. Claymaterialsused to provide the plasticity needed to obtain a defined form. These include $\mathrm{Al}, \mathrm{Si}$ and a proportion of $\mathrm{Ca}, \mathrm{Fe}$, and $\mathrm{Ti}$.

2. Fluxing materialssuch as feldspars, pegmatites etc., which, produce vitreous phases during firing that, act as particle-particle adhesives and promote solid-solid reactions; these contribute
$\mathrm{Na}, \mathrm{K}, \mathrm{Al}$ and $\mathrm{Si}$.

3. Other materials such as talc, silica, $\mathrm{CaCO} 3$ etc. (the so-called "inert" materials), used to obtain a certain type of performance; these largely contribute $\mathrm{Ca}, \mathrm{Mg}$ and $\mathrm{Si}$.

4. Additives: largely employed to improve the rheology of aqueous solutions; these may be inorganic or organic which only limited amounts $(<1 \%)$ are introduced into the bodies.

In summing up the main effects of each chemical component in a tile body, it can be stated that; the presence of oxides effects; $\mathrm{Al} 2 \mathrm{O} 3$ is used as a refractory characteristics and plasticity (associated with clayey materials). $\mathrm{SiO} 2$ gives structure. $\mathrm{Fe} 2 \mathrm{O} 3$ and $\mathrm{TiO} 2$ change the color and sometimes, fluxing properties. $\mathrm{CaO}$ and $\mathrm{MgO}$ controlling shrinkage, via the formation of calcium and magnesium silicates. $\mathrm{K} 2 \mathrm{O}$ and $\mathrm{Na} 2 \mathrm{O}$ are used as fluxes which form vitreous phases.

The quality of tiles is controlled by three factories; shrinkage, water absorption and bending strength according to international standard limit ofKonta, (1979) after system of firing as shown in (Table 5).

- Water absorption can be determined by the following formula: $\mathrm{E}=\mathrm{M} 2-\mathrm{M} 1 \times 100$ Where, $\mathrm{E}$ is water absorption, M1 is the weight of the dry tile and M2 is the weight of the humid tile.

- Bending strength can be determined by the following formula: B.S. $=3 \mathrm{FL} / 2 \mathrm{BH} 2$ Where $\mathrm{F}$ is the applied bending strength (in Newton), L is the distance between the supporting rollers (inter-axis in $\mathrm{mm}$ ), $\mathrm{B}$ is the tile width and $\mathrm{H}$ is the minimum thickness of the measured long of the breaking edge (in $\mathrm{mm}$ ).

- Shrinkage is the rate of change in length and width for inspection sample. Shrinkage is directly proportional with water absorption and bending strength. It is expressed by the formula:Shr. $=\mathrm{L} 2-\mathrm{L} 1 / \mathrm{L} 1 \mathrm{Where}, \mathrm{L} 1$ is the length after ignition and L2 is the length before ignition.

6.1. Importance of Feldspar in the Ceramic Industry

The function of feldspar in ceramic bodies is that of a flux is which it takes a part in physicochemical reactions with other crystalline phases. 
The old conception that the feldspar serves as a bond for the crystalline phases is being rejected and current theories consider that, the bonding of grains and formation of a dense mass is due to a deep inter-diffusion of phases. Budnikov and Gevorkyan, (1952) considered that during the firing of a ceramic body which is composed of feldspar and clay, the first glassy phase to be formed is due to a ternary eutectic. With pure materials and equilibrium conditions the temperature of the eutectic formation would be 990 $\pm 20 \circ \mathrm{C}$ with a pure potash feldspar or $1050 \pm$ $10 \circ \mathrm{C}$ with pure soda feldspar, and the amount of melt formed would vary with the amount of feldspar present.

The principal use of feldspar in ceramic industry primarily as fluxing agent is in the manufacture of stoneware $(5-20 \%)$, and in greater amounts in the manufacture of hard-china (about $25 \%$ ), soft-china, sanitary-china, vitreous-china $(20 \%-40 \%)$ and in ceramic glaze and enamels. The feldspar flour acts in green dried and mildly fired ceramic masses as a skeleton former or filler, similar to milled quartz. It heightens the body if fired below $1100 \mathrm{oC}$ (enhancing its porosity), whereas above $1100 \mathrm{oC}$, it fuses and contributes to higher density of the body. It causes a considerable shrinkage of the body in the temperature range between $1140 \mathrm{oC}$ to $1350 \mathrm{oC}$ due to verification and fusion. Potash feldspar lowers thermal shrinkage, whereas sodium feldspar lowers thermal expansion. The resulting feldspar melting is characterized by its relatively high viscosity which prevents deformation in even the hard-china products fired in the range $1410 \mathrm{oC}$ to $1435 \mathrm{oC}$. Potash feldspar gives glass a higher viscosity, high strength of the product and greater transparency in comparison with sodium feldspar. Alkali feldspars of highest mineral and chemical purity are used as china glaze. They contribute substantially to the luster, transparency and purity of glaze.

Generally, the using of granites is more expensive for ceramics production, whereas the feldspars must be isolated by using floatation method to remove micas. This assumption is supported by the self-separation of feldspars in zoned pegmatites and placer deposits.
6.2. Comparisons between Standard Feldspar used as a Ceramic Row Material and Abu Sheih Pegmatite

The standard feldspar used as a ceramic row material inCeramica Cleopatra Company as fluxing material in floor tile is compared with Abu Sheih pegmatites to study the suitability of Abu Sheih pegmatite for ceramic industry.

\section{1- X-ray powder diffraction (XRD)}

When comparing the X-ray diffraction analysis of Abu-Sheih pegmatites with the standard $\mathrm{X}$-ray diffractions analysis of ceramic feldspar it can be show that, the studied pegmatite is composed mainly of quartz, albite and microcline as that formed in the standard feldspar of the Ceramica Cleopatra Company (Figs. 19 and 20).

2- Differential thermal analysis (DTA) and Thermo Gravimetric analysis (TGA)

Thermo gravimetric analysis (TGA) is a thermal analysis technique which measures the weight change in a material as a function of temperature and time, in a controlled environment. This can be very useful to investigate the thermal stability of a material, or to investigate its behavior in different atmospheres (e.g. inert or oxidizing). It is suitable for use with all types of solid materials, including organic or inorganic materials.

Differential thermal analysis (DTA) is a calorimetric technique, recording the temperature and heat flow associated with thermal transitions in a material. This enables phase transitions to be determined (e.g. melting point, glass transition temperature, crystallization etc.).

In this study, standard sample of feldspar and sample of Abu Sheih pegmatites inspected by TGA and DTA analysis, the extracted chart (Figs. 21 and 22) indicated that;

DTA gives endothermic peak at $563^{\circ} \mathrm{C}, 0.232$ $\mu \mathrm{v} / \mathrm{mg}$ for standard feldspar at the same point. The TG curve gives loss in mass equals $-0.56 \%$ as well as in the test of pegmatites. DTA gives endothermic peak at $563.2^{\circ} \mathrm{C}, 0.127 \mu \mathrm{v} / \mathrm{mg}$ and at the same point the TG curve gives change in mass equals $0.19 \%$ refers to silica (quartz) transformation from alpha quartz to beta quartz. 
DTA gives exothermic peak at $951.9{ }^{\circ} \mathrm{C}$, $0.076 \mu \mathrm{v} / \mathrm{mg}$ for standard feldspar and this peak is not found in pegmatites probably refers to volatile matter as $\mathrm{CO}$ 2.This may bedue to the presence of $\mathrm{MgCO}$, $\mathrm{CaCO} 3$; So the TG gives total loss in mass equals $-1.31 \%$ in standard feldspar, but in studied pegmatites the total loss in mass equals -0.16 .

DTA gives endothermic peak at $953.6{ }^{\circ} \mathrm{C}$, $0.179 \mu \mathrm{v} / \mathrm{mg}$ for standard feldspar; at the same point the TG curve gives loss in mass equals $-1.07 \%$ as well as in the test of pegmatites. DTA gives endothermic peak at $952.4 \mathrm{C}^{\circ}, 0.017 \mu \mathrm{v} /$ $\mathrm{mg}$ and at the same point, the TG curve gives loss in mass equals $0.01 \%$ indicating its allotropic transformation.

\section{Fusibility test}

Temperature in which a substance changes the materials state from solid to liquid. Under standard atmospheric pressure different pure crystalline solids will melt at a different specific temperature; thus melting point is a characteristic for a substance and can be used to identify it. When heat is applied continuously and in sufficient quantity to such solids, the temperature rises steadily until it reaches the point at which liquefaction occurs. Here the rise ceases and no further change in temperature is observed until all of the substance has been converted to liquid. When standard feldspar and the studied pegmatites offer to ignition started by $50^{\circ} \mathrm{C}$ and excesses gradually $2^{\circ} \mathrm{C}$ per minute, the softening point (sintering) happen at $1216^{\circ} \mathrm{C}$ for standard feldspar and $1249^{\circ} \mathrm{C}$ for studied pegmatites, Melting point (fusion) was detected at $1441^{\circ} \mathrm{C}$ for standard feldspar and $1445^{\circ} \mathrm{C}$ for studied pegmatites (Figs. 23 and 24), the standard feldspar is also powerful flux than studied pegmatites.

\section{Pegmatite as Ceramic Row Material}

Many tests were carried out on the pegmatites to as adapted for ceramic industry. These tests include determination of thermal linear expansion, shrinkage, water absorption and bending strength. These tests were applied in biscuit (small tile) of pegmatite sample that prepared as follow:-

1- Row material preparation, where the large size must be crushed of size $1 \mathrm{~mm}$ to $3 \mathrm{~mm}$.

2- Take the row material for grinding the par- ticle size distribution of both standard feldspar and pegmatites after grinding (Table 6), and put the slip in the dryer about 90 minutes at $100^{\circ} \mathrm{C}$.

3- Make hand grinding to become less than 600 micron with $5 \%$ of spray water.

4- Pressing the sample at 110 bar.

5- Firing of sample at $1200-1220^{\circ} \mathrm{C}$ for 97 minutes.

\subsubsection{Colors:}

The fired pegmatite samples are characterized by the light color (Fig. 25).

6.3.2. Thermal expansion(revealed by a Misura vertical optical heating microscope):

Thermal expansion for standard feldspar compared with Abu Sheih pegmatites (Fig. 27) indicates that; physical properties of Abu Sheih pegmatites are more or less near the standard feldspar.

Table (1):Major oxide analyses (wt \%), CIPW norms, differentiation index (D.I.) and trace elements for Abu Sheih pegmatite.

\begin{tabular}{|c|c|c|c|c|c|c|}
\hline Sample. NO & 3 & 8 & 14 & 17 & 29 & 23 \\
\hline \multicolumn{7}{|c|}{ Major Oxides (wt. \%) } \\
\hline $\mathrm{SiO}_{2}$ & 70.39 & 69.70 & 69.88 & 70.12 & 70.61 & 69.14 \\
\hline $\mathrm{TiO}_{2}$ & 0.24 & 0.13 & 0.16 & 0.11 & 0.13 & 0.57 \\
\hline $\mathrm{AL}_{2} \mathrm{O}_{3}$ & 14.08 & 15.22 & 15.15 & 15.32 & 15.25 & 14.54 \\
\hline $\mathrm{Fe}_{2} \mathrm{O}_{3}$ & 1.55 & 1.05 & 0.72 & 0.62 & 1.11 & 1.45 \\
\hline $\mathrm{FeO}$ & 1.60 & 0.31 & 0.35 & 0.36 & 0.61 & 0.87 \\
\hline $\mathrm{MnO}$ & 0.06 & 0.04 & 0.02 & 0.05 & 0.06 & 0.06 \\
\hline $\mathrm{MgO}$ & 0.54 & 0.39 & 0.31 & 0.43 & 0.18 & 1.04 \\
\hline $\mathrm{CaO}$ & 1.79 & 1.00 & 1.22 & 1.20 & 0.86 & 1.32 \\
\hline $\mathrm{Na}_{2} \mathrm{O}$ & 2.64 & 3.30 & 2.75 & 2.76 & 3.00 & 3.2 \\
\hline $\mathrm{K}_{2} \mathrm{O}$ & 6.02 & 7.47 & 7.43 & 7.79 & 7.15 & 5.82 \\
\hline $\mathrm{P}_{2} \mathrm{O}_{5}$ & 0.08 & 0.11 & 0.14 & 0.06 & 0.13 & 0.14 \\
\hline 1.O.I & 0.90 & 1.12 & 1.60 & 1.13 & 0.74 & 1.9 \\
\hline Total & 99.89 & 99.84 & 99.73 & 99.95 & 99.83 & 100.05 \\
\hline \multicolumn{7}{|c|}{ CIPW norms } \\
\hline Q & 27.21 & 19.73 & 23.17 & 21.42 & 24.20 & 24.69 \\
\hline Or & 35.97 & 44.76 & 44.79 & 46.63 & 42.68 & 35.07 \\
\hline $\mathrm{Ab}$ & 22.54 & 28.25 & 23.68 & 23.60 & 25.59 & 27.55 \\
\hline $\mathrm{An}$ & 8.50 & 4.37 & 5.33 & 5.67 & 3.54 & 5.84 \\
\hline $\mathrm{C}$ & 0.12 & 0.10 & 0.66 & 0.27 & 1.28 & 0.87 \\
\hline Hy & 2.73 & 0.99 & 0.79 & 1.15 & 0.46 & 2.65 \\
\hline Mt & 2.27 & 0.76 & 0.74 & 0.91 & 1.62 & 1.37 \\
\hline Il & 0.46 & 0.25 & 0.31 & 0.21 & 0.25 & 1.10 \\
\hline Ap & 0.18 & 0.24 & 0.31 & 0.13 & 0.29 & 0.31 \\
\hline D.I & 85.72 & 92.74 & 91.64 & 91.65 & 92.47 & 87.31 \\
\hline \multicolumn{7}{|c|}{ Trace elements (ppm) } \\
\hline $\mathrm{Cr}$ & 13 & 15 & 10 & 16 & 12 & 20 \\
\hline $\mathrm{Ni}$ & 5 & 3 & u.d & 64 & 7 & 12 \\
\hline $\mathrm{Cu}$ & 11 & 8 & 7 & 9 & 8 & 8 \\
\hline $\mathrm{Zn}$ & 17 & 8 & 24 & 20 & 23 & 21 \\
\hline $\mathrm{Zr}$ & 41 & 45 & 7 & 79 & 120 & 139 \\
\hline $\mathrm{Rb}$ & 173 & 96 & 398 & 138 & 222 & 101 \\
\hline $\mathrm{Y}$ & 14 & 21 & 8 & 27 & 51 & 72 \\
\hline $\mathrm{Ba}$ & 221 & 51 & 88 & 104 & 231 & 164 \\
\hline $\mathrm{Pb}$ & 17 & 6 & 22 & 14 & 11 & 11 \\
\hline $\mathrm{Sr}$ & 2 & 2 & u.d & 4 & 5 & 5 \\
\hline $\mathrm{Ga}$ & 8 & 8 & 12 & 10 & 6 & 9 \\
\hline V & 5 & 2 & 2 & 2 & 5 & 4 \\
\hline $\mathrm{Nb}$ & 6 & 7 & u.d & 13 & 19 & 24 \\
\hline
\end{tabular}


Table (2): Range and average content of major oxides and trace elements of Abu Sheih pegmatites and their host rock (old and Syenogranites)

\begin{tabular}{||c||c|c|c||c|c|c||c|c|c||}
\hline \multicolumn{1}{|c||}{} & \multicolumn{3}{c||}{ Granodiorites } & \multicolumn{3}{c||}{ Syenogranites } & \multicolumn{3}{c||}{ pegmatites } \\
\cline { 2 - 12 } & Min. & Max. & Av. & Min. & Max. & Av. & Min. & Max. & Av. \\
\hline \hline $\mathrm{SiO}_{2}$ & 66.66 & 67.31 & 66.94 & 74.40 & 76.04 & 75.14 & 69.14 & 70.61 & 69.97 \\
\hline $\mathrm{TiO}_{2}$ & 0.12 & 0.48 & 0.22 & 0.00 & 0.10 & 0.06 & 0.11 & 0.57 & 0.22 \\
\hline $\mathrm{AL}_{2} \mathrm{O}_{3}$ & 13.87 & 15.21 & 14.66 & 12.90 & 13.81 & 13.37 & 14.08 & 15.32 & 14.93 \\
\hline $\mathrm{Fe}_{2} \mathrm{O}_{3}$ & 1.26 & 1.75 & 1.43 & 0.60 & 1.00 & 0.79 & 0.62 & 1.55 & 1.08 \\
\hline $\mathrm{FeO}$ & 1.53 & 2.11 & 1.74 & 0.02 & 0.35 & 0.20 & 0.31 & 1.60 & 0.68 \\
\hline $\mathrm{MnO}$ & 0.2 & 0.19 & 0.17 & 0.01 & 0.05 & 0.03 & 0.02 & 0.06 & 0.05 \\
\hline $\mathrm{MgO}$ & 1.23 & 1.41 & 1.32 & 0.15 & 0.40 & 0.27 & 0.18 & 1.04 & 0.48 \\
\hline $\mathrm{CaO}$ & 4.03 & 5.61 & 4.86 & 0.40 & 0.63 & 0.51 & 0.86 & 1.79 & 1.23 \\
\hline $\mathrm{Na}_{2} \mathrm{O}$ & 3.86 & 4.16 & 4.03 & 3.90 & 4.30 & 4.10 & 2.75 & 3.30 & 2.94 \\
\hline $\mathrm{K}_{2} \mathrm{O}$ & 2.77 & 3.79 & 3.11 & 4.22 & 5.10 & 4.75 & 5.82 & 6.02 & 6.95 \\
\hline $\mathrm{P}_{2} \mathrm{O}_{5}$ & 0.09 & 0.17 & 0.12 & 0.08 & 0.20 & 0.12 & 0.06 & 0.14 & 0.11 \\
\hline $1 . \mathrm{O} . \mathrm{I}$ & 0.97 & 1.65 & 1.20 & 0.50 & 0.81 & 0.69 & 0.90 & 1.60 & 1.23 \\
\hline \hline $\mathrm{Cr}$ & 11 & 16 & 13 & 13 & 40 & 27 & 12 & 20 & 14 \\
\hline $\mathrm{Ni}$ & 4 & 23 & 9 & 3 & 13 & 7 & ud & 64 & 15 \\
\hline $\mathrm{Cu}$ & 24 & 34 & 28 & 4 & 9 & 6 & 7 & 11 & 9 \\
\hline $\mathrm{Zn}$ & 46 & 79 & 56 & 31 & 58 & 42 & 8 & 24 & 19 \\
\hline $\mathrm{Zr}$ & 105 & 353 & 162 & 92 & 433 & 214 & 7 & 139 & 72 \\
\hline $\mathrm{Rb}$ & 31 & 78 & 45 & 86 & 200 & 161 & 96 & 398 & 188 \\
\hline $\mathrm{Y}$ & 7 & 26 & 12 & 48 & 191 & 99 & 8 & 72 & 32 \\
\hline $\mathrm{Ba}$ & 657 & 1624 & 949 & 95 & 587 & 243 & 51 & 231 & 143 \\
\hline $\mathrm{Pb}$ & 5 & 15 & 11 & 9 & 15 & 12 & 6 & 22 & 14 \\
\hline $\mathrm{Sr}$ & 172 & 543 & 258 & 3 & 19 & 9 & $\mathrm{ud}$ & 5 & 3 \\
\hline $\mathrm{Ga}$ & 6 & 9 & 7 & 4 & 8 & 6 & 6 & 12 & 9 \\
\hline $\mathrm{V}$ & 21 & 40 & 29 & 2 & 16 & 6 & 2 & 5 & 3 \\
\hline $\mathrm{Nb}$ & 6 & 19 & 9 & 16 & 74 & 38 & $\mathrm{ud}$ & 24 & 12 \\
\hline
\end{tabular}

Table (3):Pegmatites field measurement result, absorbed $\gamma$ - dose rate (D), annual effective dose (Eff D), radium equivalent activity (Raeq), external and internal hazard indices (Hex and Hin) and gamma activity index (I $\gamma)$.

\begin{tabular}{|c|c|c|c|c|c|c|c|c|c|c|}
\hline $\begin{array}{l}\text { Sample } \\
\text { No }\end{array}$ & eU & eTh & eTh/eU & $\mathbf{K} \%$ & Dose & $\begin{array}{l}\text { Eff. } \\
\text { Dose }\end{array}$ & Raeq & Hex & Hin & $\mathbf{I} \gamma$ \\
\hline $3-1$ & 2.20 & 2.40 & 1.10 & 4.80 & 2.67 & 0.02 & 6.00 & 0.02 & 0.02 & 0.04 \\
\hline $3-2$ & 1.50 & 3.50 & 2.30 & 3.20 & 2.94 & 0.02 & 6.75 & 0.02 & 0.02 & 0.05 \\
\hline $3-3$ & 0.90 & 6.30 & 7.00 & 3.30 & 4.36 & 0.03 & 10.15 & 0.03 & 0.03 & 0.07 \\
\hline $3-4$ & 3.30 & 4.80 & 1.50 & 3.10 & 4.55 & 0.03 & 10.40 & 0.03 & 0.04 & 0.07 \\
\hline $3-5$ & 2.10 & 5.20 & 2.50 & 3.40 & 4.25 & 0.03 & 9.79 & 0.03 & 0.03 & 0.07 \\
\hline $8-1$ & 2.00 & 4.70 & 2.40 & 3.20 & 3.90 & 0.03 & 8.96 & 0.02 & 0.03 & 0.06 \\
\hline $8-2$ & 4.80 & 4.70 & 1.00 & 3.40 & 5.20 & 0.04 & 11.78 & 0.03 & 0.04 & 0.08 \\
\hline $8-3$ & 2.30 & 7.10 & 3.10 & 3.20 & 5.48 & 0.04 & 12.69 & 0.03 & 0.04 & 0.09 \\
\hline $8-4$ & 2.60 & 4.60 & 1.80 & 1.80 & 4.05 & 0.03 & 9.31 & 0.03 & 0.03 & 0.06 \\
\hline $8-5$ & 2.30 & 6.30 & 2.70 & 1.70 & 4.94 & 0.03 & 11.43 & 0.03 & 0.04 & 0.08 \\
\hline $14-1$ & 4.00 & 5.20 & 1.30 & 5.00 & 5.20 & 0.04 & 11.81 & 0.03 & 0.04 & 0.08 \\
\hline $14-2$ & 3.50 & 6.40 & 1.80 & 5.30 & 5.70 & 0.04 & 13.05 & 0.04 & 0.04 & 0.09 \\
\hline $14-3$ & 4.50 & 15.30 & 3.40 & 6.10 & 11.57 & 0.08 & 26.83 & 0.07 & 0.08 & 0.19 \\
\hline $14-4$ & 7.40 & 27.20 & 3.70 & 6.00 & 20.10 & 0.14 & 46.72 & 0.13 & 0.15 & 0.33 \\
\hline $14-5$ & 5.50 & 23.20 & 4.20 & 5.20 & 16.77 & 0.12 & 39.04 & 0.11 & 0.12 & 0.27 \\
\hline $14-6$ & 2.50 & 13.10 & 5.20 & 6.50 & 9.34 & 0.07 & 21.71 & 0.06 & 0.07 & 0.15 \\
\hline $17-1$ & 1.70 & 6.90 & 4.10 & 7.00 & 5.24 & 0.04 & 12.10 & 0.03 & 0.04 & 0.09 \\
\hline $17-2$ & 4.10 & 4.20 & 1.00 & 4.60 & 4.62 & 0.03 & 10.45 & 0.03 & 0.04 & 0.07 \\
\hline $17-3$ & 4.20 & 3.70 & 0.90 & 5.50 & 4.40 & 0.03 & 9.91 & 0.03 & 0.04 & 0.07 \\
\hline $17-4$ & 2.10 & 2.70 & 1.30 & 5.10 & 2.81 & 0.02 & 6.35 & 0.02 & 0.02 & 0.04 \\
\hline $17-5$ & 3.40 & 5.50 & 1.60 & 5.40 & 5.12 & 0.04 & 11.67 & 0.03 & 0.04 & 0.08 \\
\hline $17-6$ & 3.00 & 7.40 & 2.50 & 5.30 & 6.08 & 0.04 & 13.98 & 0.04 & 0.05 & 0.10 \\
\hline $23-1$ & 8.70 & 67.40 & 7.70 & 4.10 & 44.90 & 0.31 & 105.30 & 0.28 & 0.31 & 0.70 \\
\hline $23-2$ & 5.90 & 31.80 & 5.40 & 0.90 & 22.10 & 0.15 & 51.63 & 0.14 & 0.15 & 0.36 \\
\hline $23-3$ & 11.10 & 46.70 & 4.20 & 2.90 & 33.46 & 0.23 & 78.04 & 0.21 & 0.24 & 0.54 \\
\hline $23-4$ & 10.10 & 19.70 & 2.00 & 4.20 & 16.74 & 0.12 & 38.57 & 0.10 & 0.13 & 0.27 \\
\hline $23-5$ & 5.60 & 12.10 & 2.20 & 5.80 & 10.14 & 0.07 & 23.33 & 0.06 & 0.08 & 0.20 \\
\hline $23-6$ & 2.90 & 10.80 & 3.70 & 5.30 & 8.10 & 0.06 & 18.74 & 0.05 & 0.06 & 0.13 \\
\hline $23-7$ & 3.00 & 10.50 & 3.50 & 3.70 & 7.88 & 0.06 & 18.28 & 0.05 & 0.06 & 0.13 \\
\hline Average & 4.90 & 18.40 & 2.70 & 3.70 & 13.53 & 0.09 & 31.47 & 0.09 & 0.10 & 0.22 \\
\hline
\end{tabular}


Geology, petrography, geochemistry and Suitability

Table (4): The range of eU, eTh ppm and $\mathrm{Th} / \mathrm{U}$ ratios of the analyzed granitic and pegmatites samples compared to the published data

\begin{tabular}{|c|c|c|c|c|}
\hline \multirow{2}{*}{ Rock Types } & \multirow{2}{*}{ published data } & \multicolumn{3}{|c|}{ Averages } \\
\hline & & $\mathrm{eU}$ & $\mathrm{eTh}$ & $\mathrm{Th} / \mathrm{U}$ \\
\hline \multirow{2}{*}{ Older Granite } & Granodiorites of study area & 2.2 & 4.8 & 2.4 \\
\hline & Rogers And Adams (1969) Granitic rocks & 4 & 11 & -- \\
\hline \multirow{2}{*}{ Syenogranites } & Syenogranites of study area & 4.6 & 14.6 & 3.3 \\
\hline & Rogers And Adams (1969) Granitic rocks & 4 & 11 & -- \\
\hline \multirow{3}{*}{ pegmatite } & Pegmatites of study area & 4.9 & 18.4 & 2.8 \\
\hline & $\begin{array}{l}\text { Average of world uraniferous pegmatites } \\
\text { (Ford,1982) }\end{array}$ & 28 & 21 & 0.7 \\
\hline & $\begin{array}{c}\text { Average of Egyptian uraniferous pegmatites } \\
\text { after Heikal et al.,(2001). }\end{array}$ & $\begin{array}{c}\text { Less } \\
\text { than } 35\end{array}$ & $\begin{array}{c}\text { Less } \\
\text { than } 30\end{array}$ & $\begin{array}{c}\text { Less } \\
\text { than } 1.2\end{array}$ \\
\hline
\end{tabular}

Table (5): Shrinkage, water absorption and bending strength international standard limits (Konta, 1979)

\begin{tabular}{|l||c|c||}
\hline \multicolumn{1}{|c||}{ Characters } & Ceramic wall & Ceramic floor \\
\hline \hline Shrinkage (\%) & $0.0-0.3$ & $5.4-6.5$ \\
\hline Water absorption (\%) & $14-17$ & less than 3 \\
\hline Bending strength (N/cm2) & over 17 & over 27.5 \\
\hline \hline
\end{tabular}

Table (6):Particle size distribution of standard feldspar compared with the studied pegmatites by (SediGraphIII particle size analyzer).

\begin{tabular}{|c||c|c|}
\hline \multirow{2}{*}{ Low Diameter $(\mu \mathrm{m})$} & \multicolumn{2}{|c|}{ Cumulative Mass Finer (\%) } \\
\cline { 2 - 3 } & Standard feldspar & Abu-Sheih pegmatites \\
\hline \hline 50 & 99.7 & 87.6 \\
\hline 40 & 96.7 & 81.6 \\
\hline 30 & 88.9 & 72.1 \\
\hline 20 & 73.1 & 59.1 \\
\hline 10 & 45.0 & 39.1 \\
\hline 5 & 29.7 & 24.5 \\
\hline 4 & 25.6 & 20.2 \\
\hline 3 & 20.7 & 15.5 \\
\hline 2 & 15.5 & 10.8 \\
\hline 1 & 9.3 & 5.5 \\
\hline
\end{tabular}

Table (7): Shrinkage, water absorption (WA) and bending strength (BS) of standard feldsparof the Ceramica Cleopatra Company and Abu Sheih pegmatites.

\begin{tabular}{|c|c|c|c|c|}
\hline $\begin{array}{c}\text { Row } \\
\text { material }\end{array}$ & $\begin{array}{c}\text { Sample } \\
\text { No. }\end{array}$ & $\begin{array}{c}\text { Shrinkage } \\
(\%)\end{array}$ & $\begin{array}{c}\text { Water absorption. } \\
(\%)\end{array}$ & $\begin{array}{l}\text { Bending strength } \\
\left(\mathrm{N} / \mathrm{cm}^{2}\right)\end{array}$ \\
\hline \multirow{5}{*}{ 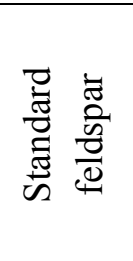 } & 1 & 7.13 & 0.00 & 58 \\
\hline & 2 & 6.75 & 0.20 & 55 \\
\hline & 3 & 5.49 & 0.30 & 53 \\
\hline & 4 & 7.15 & 0 & 60 \\
\hline & 5 & 6.87 & 0 & 56 \\
\hline \multirow{5}{*}{ 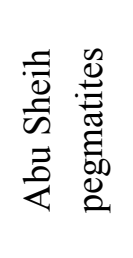 } & 1 & 10.12 & 0 & 69 \\
\hline & 2 & 9.66 & 0 & 66 \\
\hline & 3 & 10.00 & 0 & 67 \\
\hline & 4 & 9.00 & 0 & 66 \\
\hline & 5 & 10.89 & 0 & 71 \\
\hline
\end{tabular}


Ahmed El-Mezain et al .,

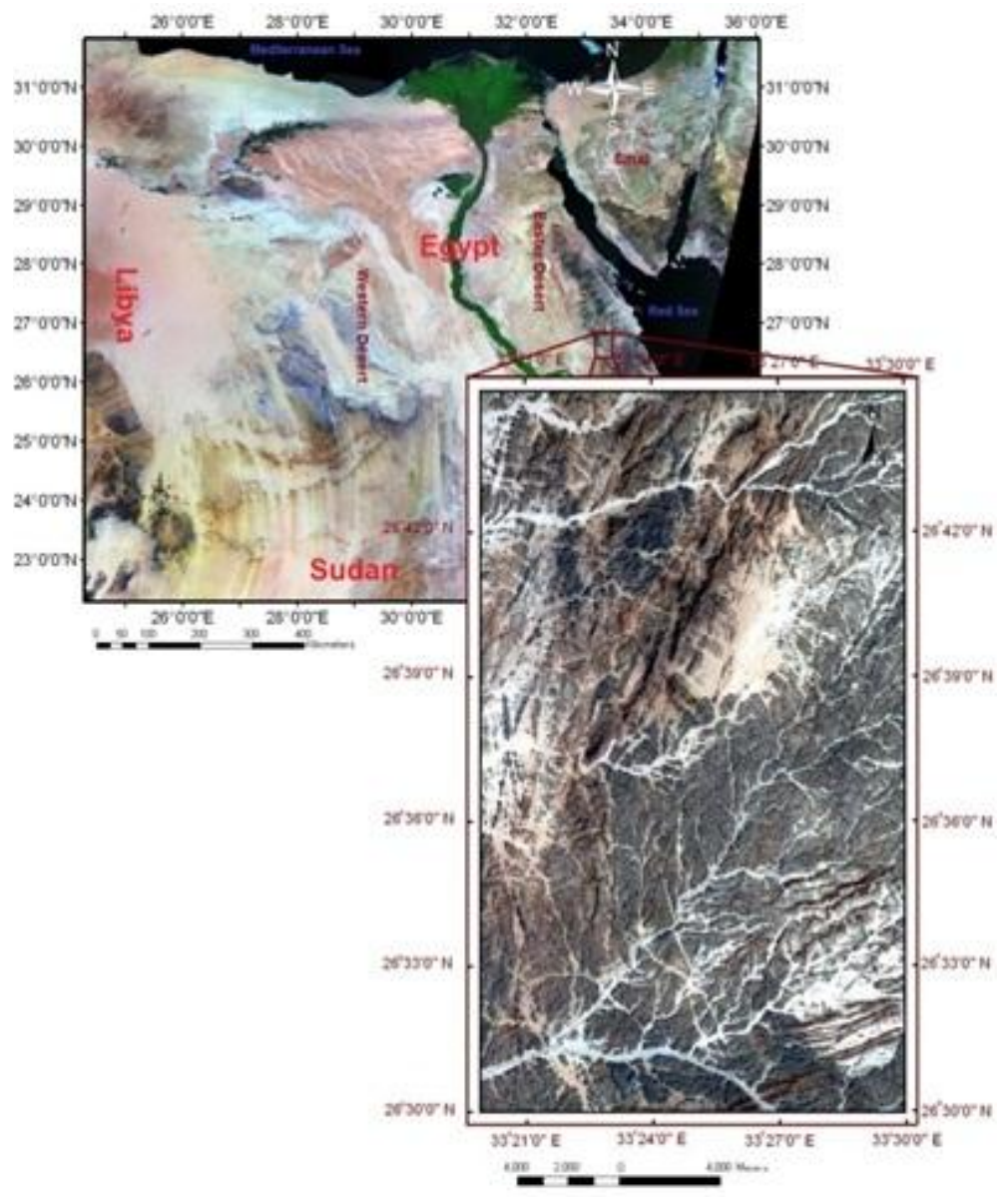

Fig (1): Landsate image shows the location of the study area.

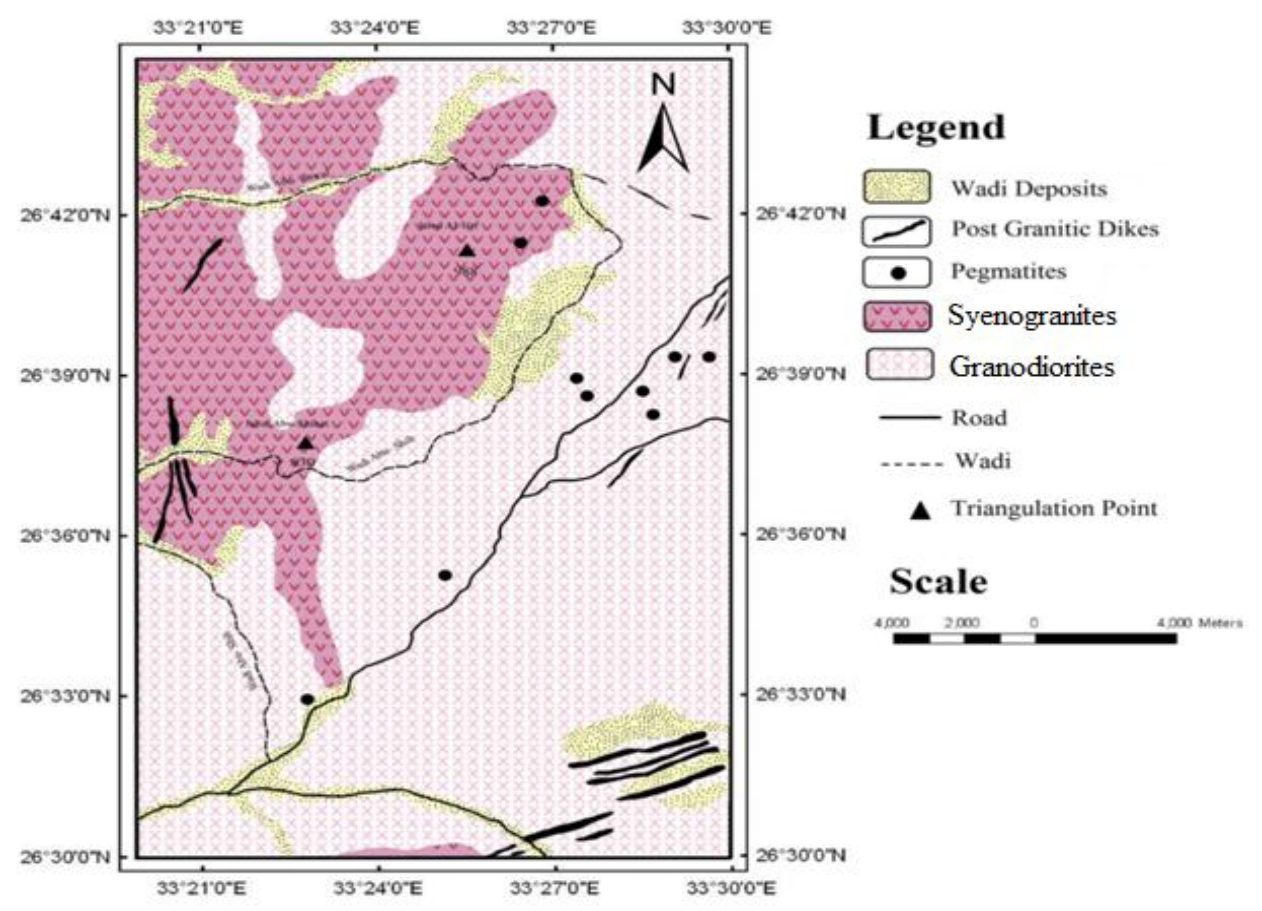

Fig (2): Geologic map of Wadi Abu Sheih area. 


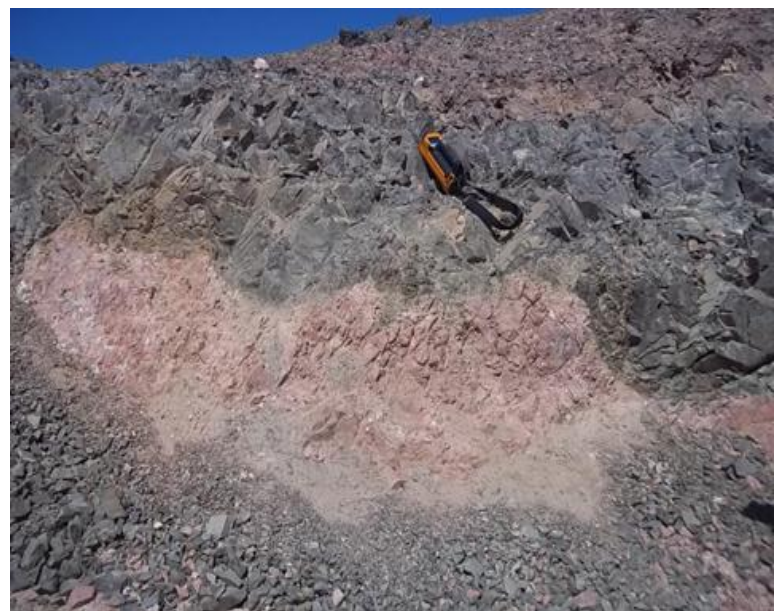

Fig. (3): Photograph showing lenticular vein-like pegmatite body invades Granodiorites and associated basic dike.

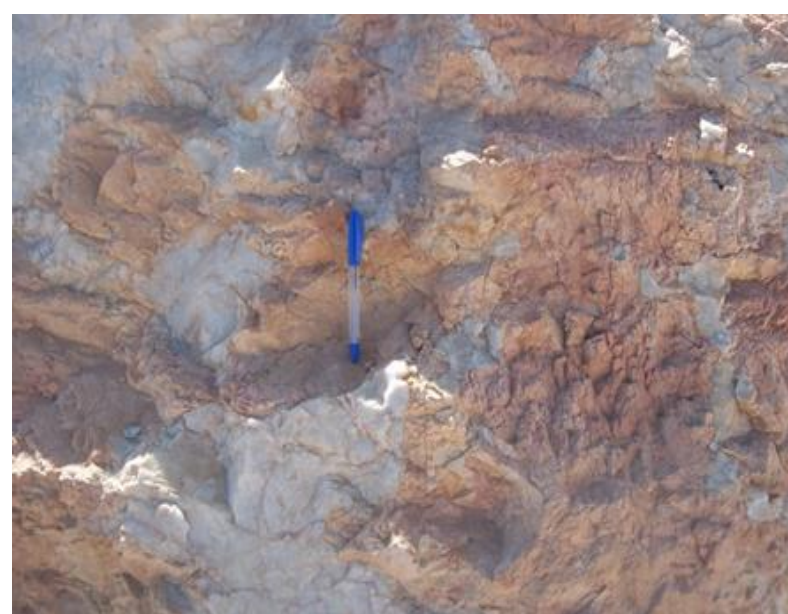

Fig. (5): Photograph exhibiting very coarse grained unzoned pegmatite composed mainly of milky quartz

and reddish pink K-feldspar.

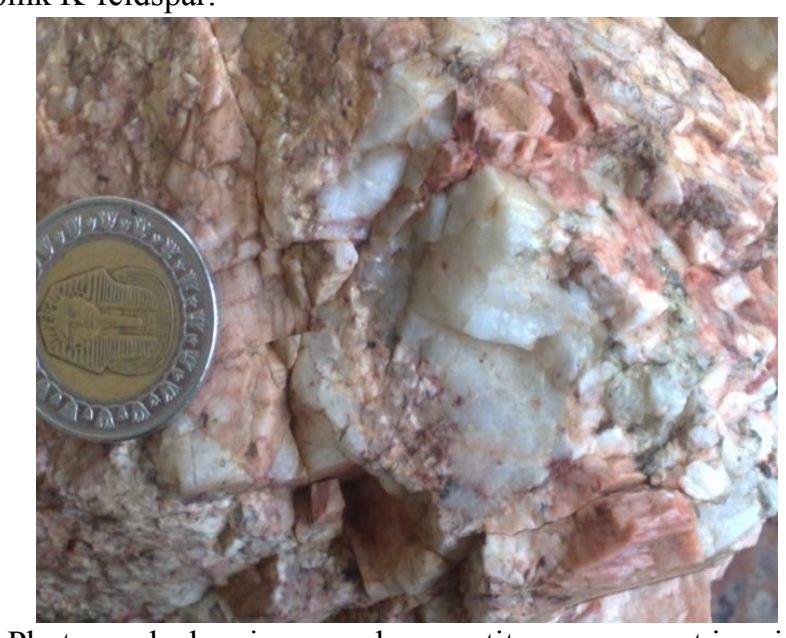

Fig. (7): Photograph showing zoned pegmatites are present in minor scales.

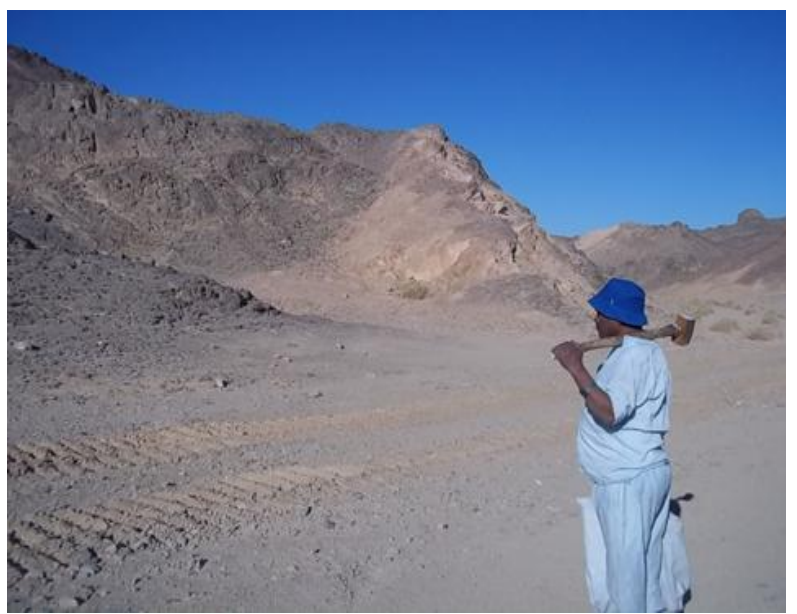

Fig. (4): Photograph showing pegmatite body invades the Granodiorites with sharp contact.

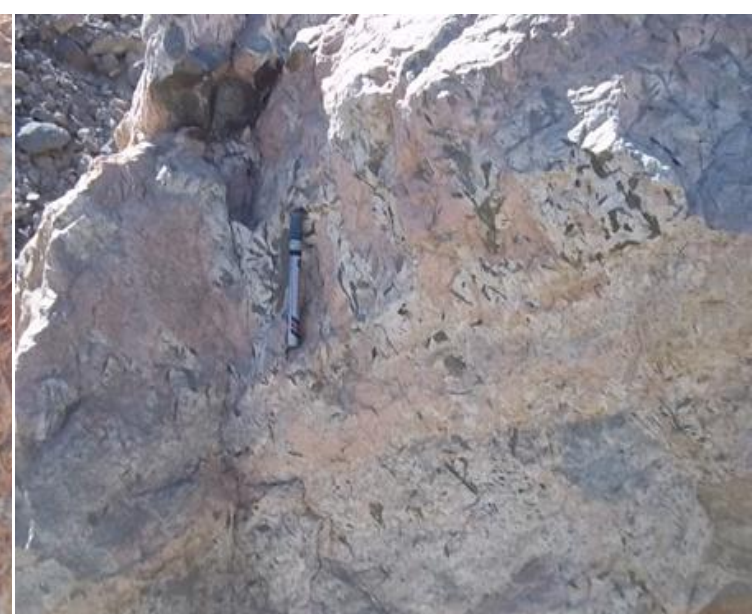

Fig. (6): Photograph showing mineralized pegmatite composed mainly of quartz, K-feldspar and biotite. 

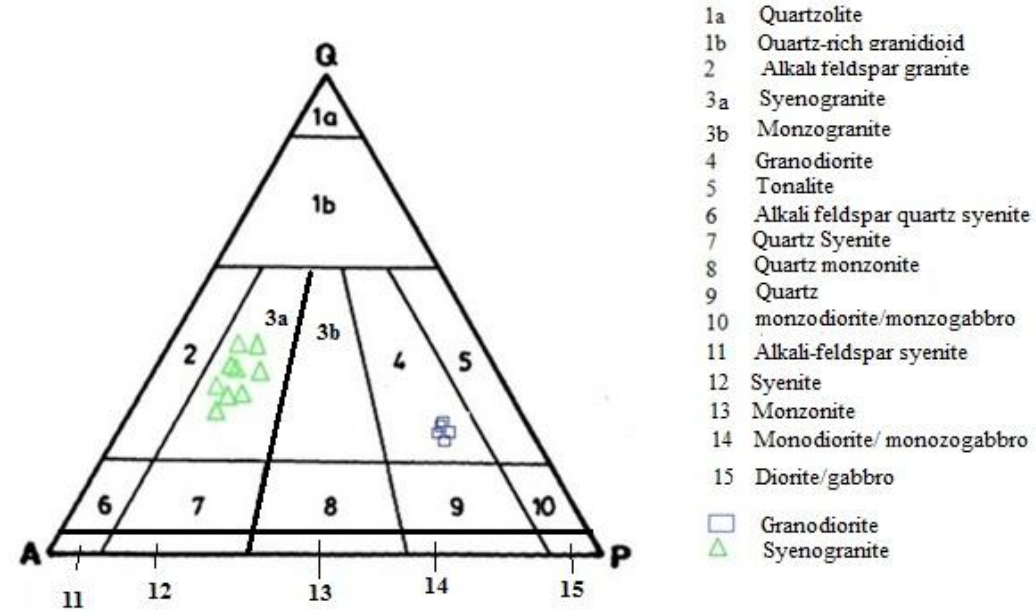

Fig (8):Plotting of Wadi Abu Sheih granitoid rocks on QAP of Streckeisen, (1976).

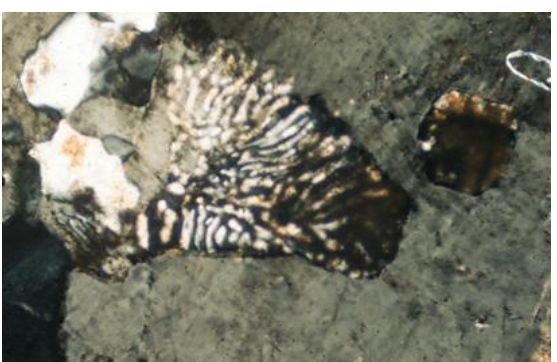

Fig. (9): Photomicrography showing myrmekitic texture in alkali feldspar microperthite. C.N., $\mathrm{X}=40$

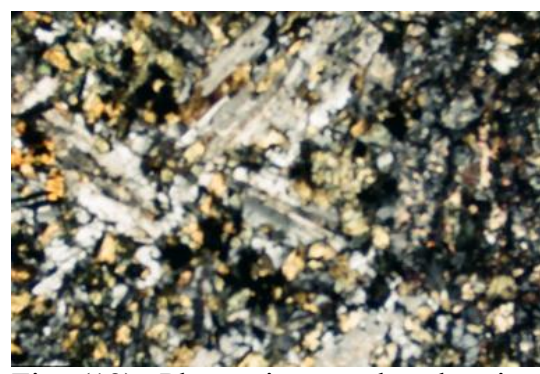

Fig. (12): Photomicrography showing cleavage in biotite and muscovite. C.N., $\mathrm{X}=40$

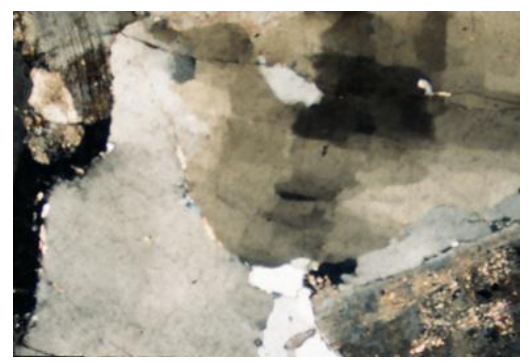

Fig (10): Photomicrography showing wavy extinction in quartz manifesting catalectic deformation. C.N., $X=40$

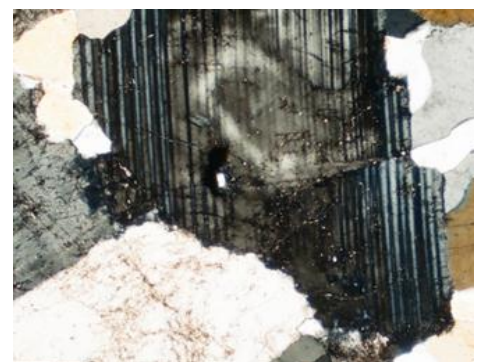

Fig. (11): Photomicrography showing subhedral to euhedral tabular crystals of plagioclase with secondary zoning. C.N., $\mathrm{X}=40$

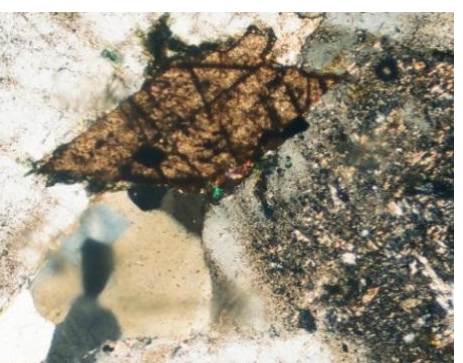

Fig. (14): Photomicrography showing euhedral crystal of titanite. C.N., $\mathrm{X}=40$

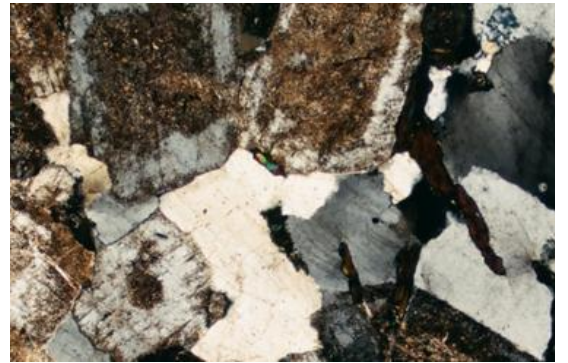

Fig. (15): Photomicrography showing graphic and micrographic texture iron oxides fills most of cracks on the plagioclase and quartz. C.N., $X=40$ 


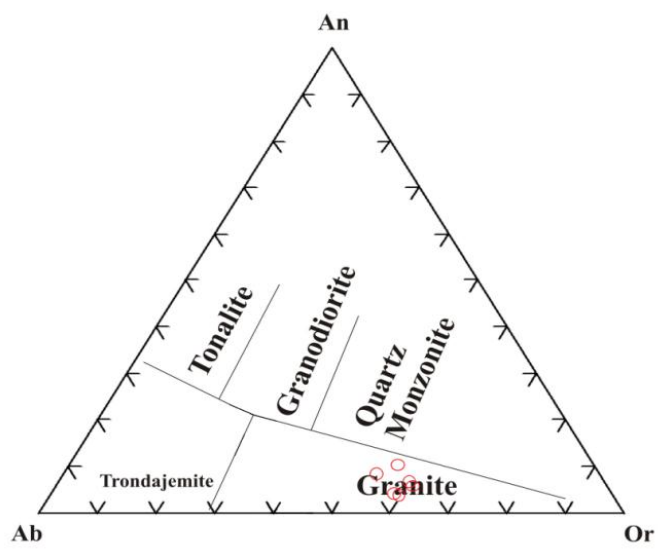

Fig. (16): Or-Ab-An ternary diagram ofO'Connor (1965) and modified by Barker (1979) for the studied pegmatite samples.

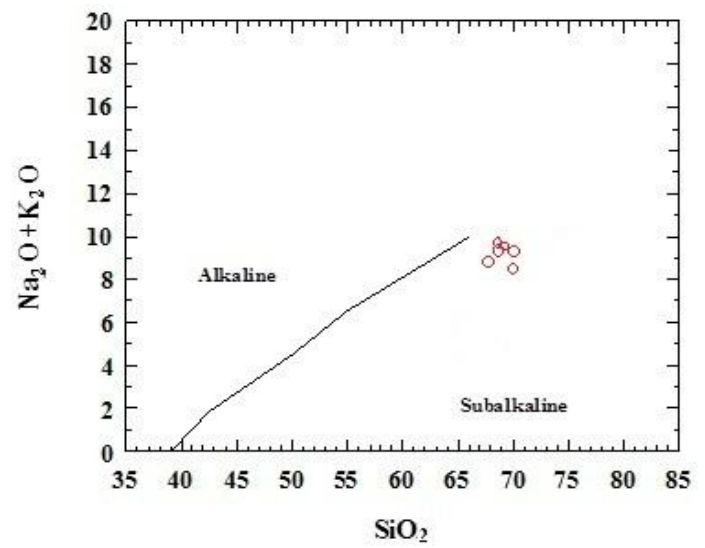

Fig. (17): Alkali-silica variation diagram ofIrvin and Baragar(1971) for the studied pegmatite samples.

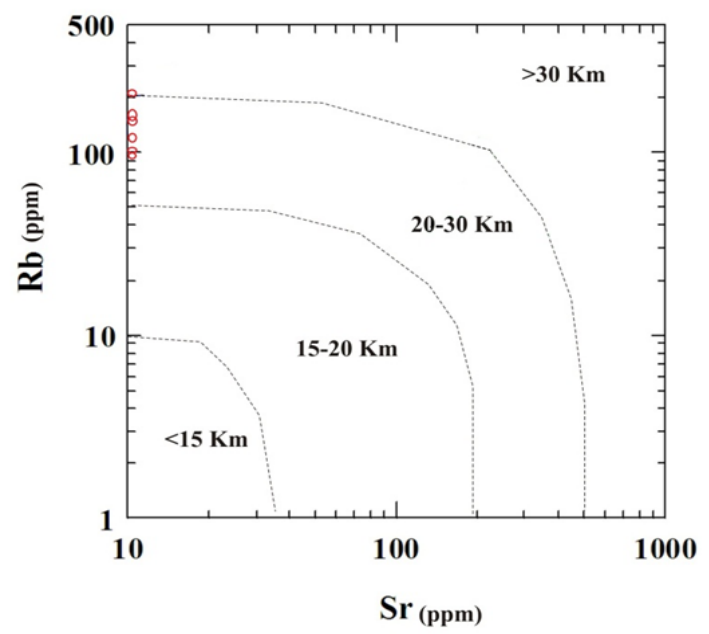

Fig. (18): Rb - Sr variation diagram according to Condie (1973) for the studied pegmatite samples.

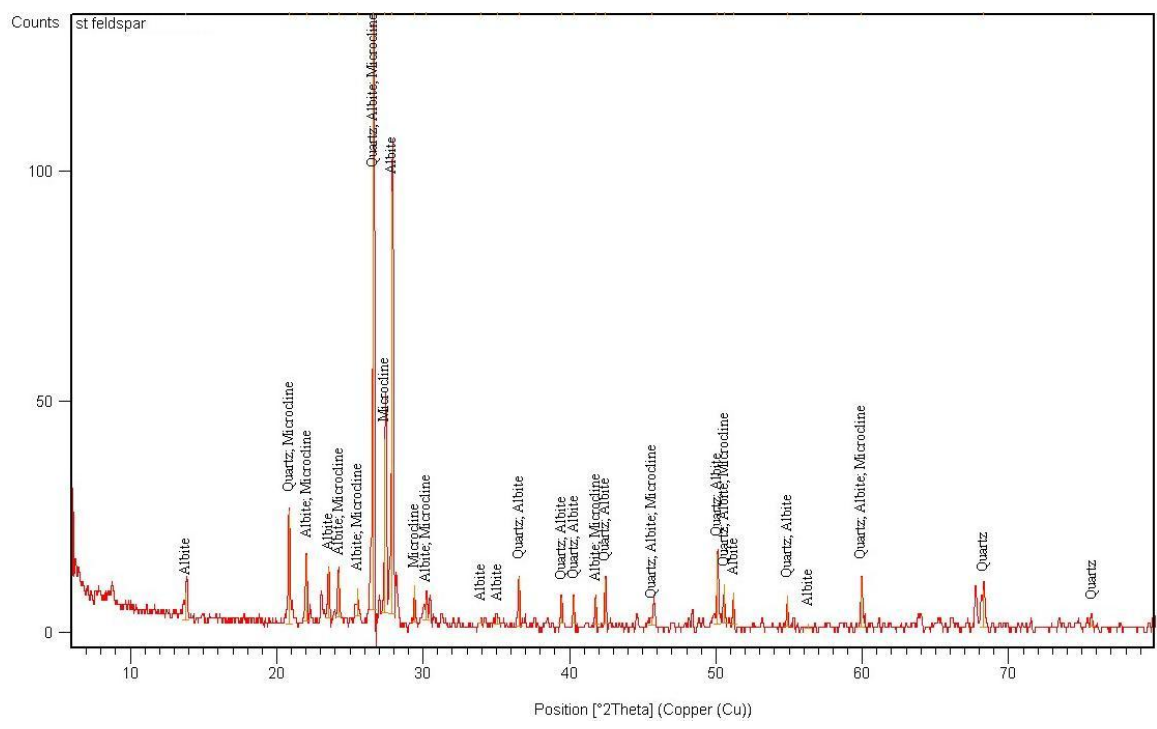

Fig (19): X-ray diffraction pattern of standard feldspar of the Ceramica Cleopatra Company 
Ahmed El-Mezain et al .,

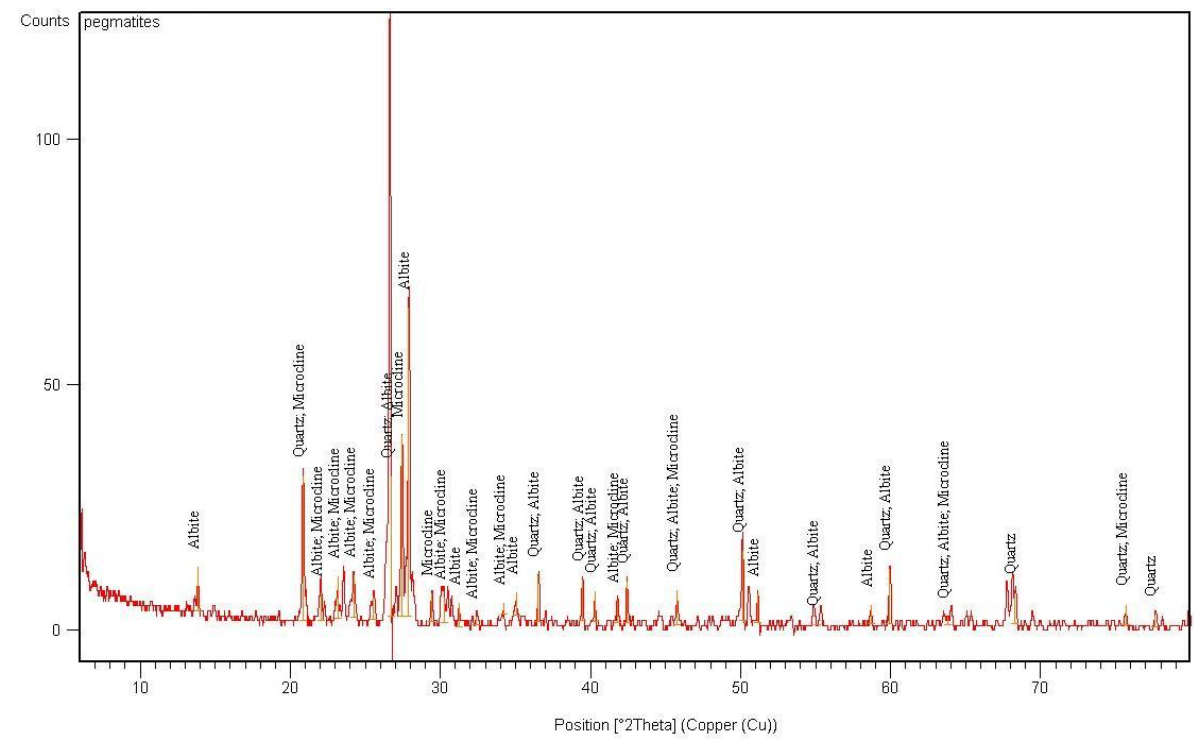

Fig (20): X-ray diffraction pattern of Abu Sheih pegmatites

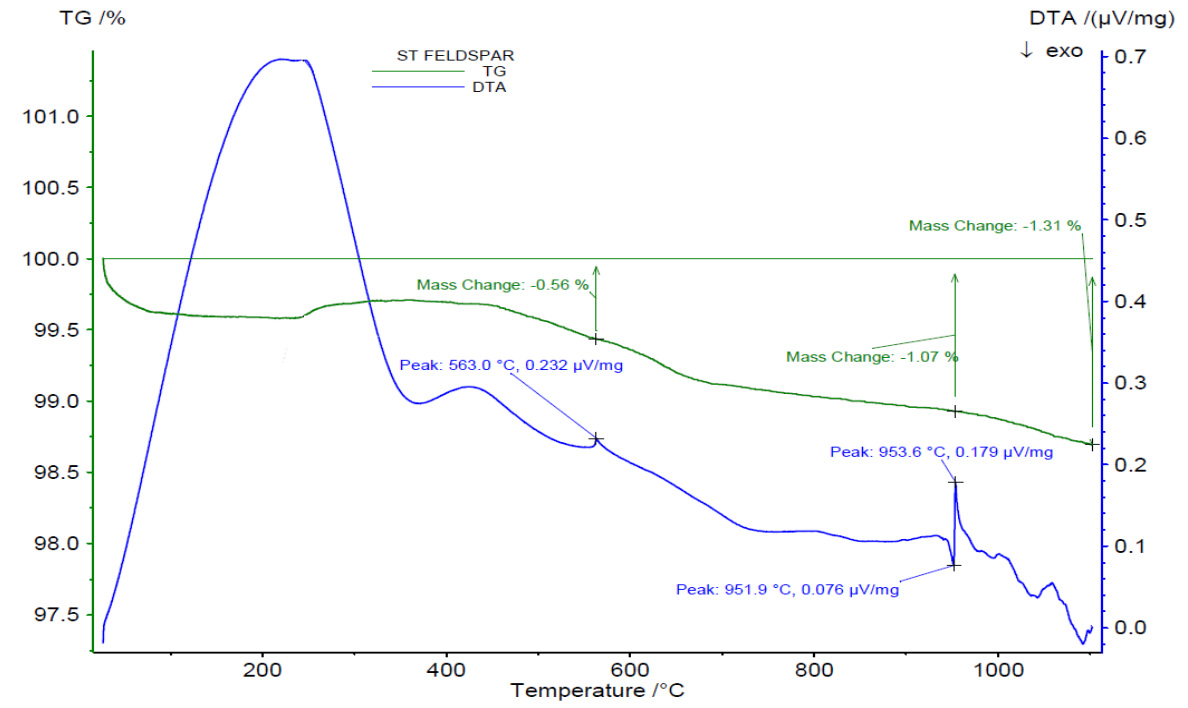

Fig (21):TGA and DTA chart of standard feldspar of the Ceramica Cleopatra Company.

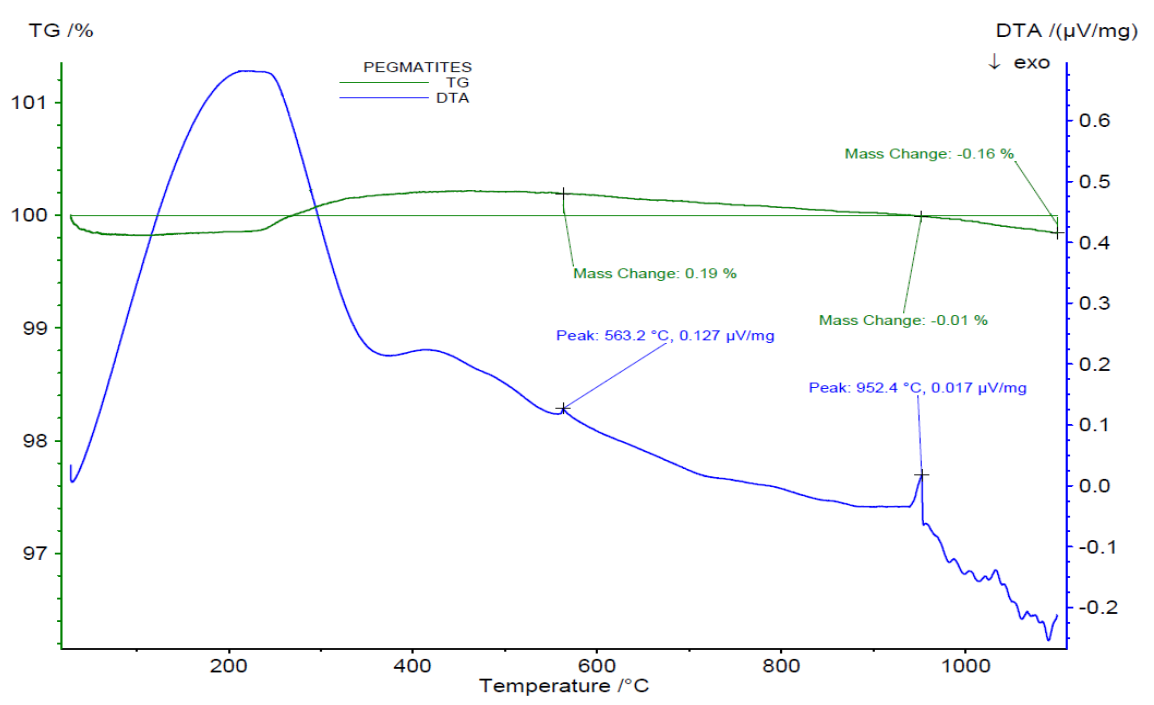

Fig (22):TGA and DTA chart of Abu Sheih pegmatites. 
Geology, petrography, geochemistry and Suitability

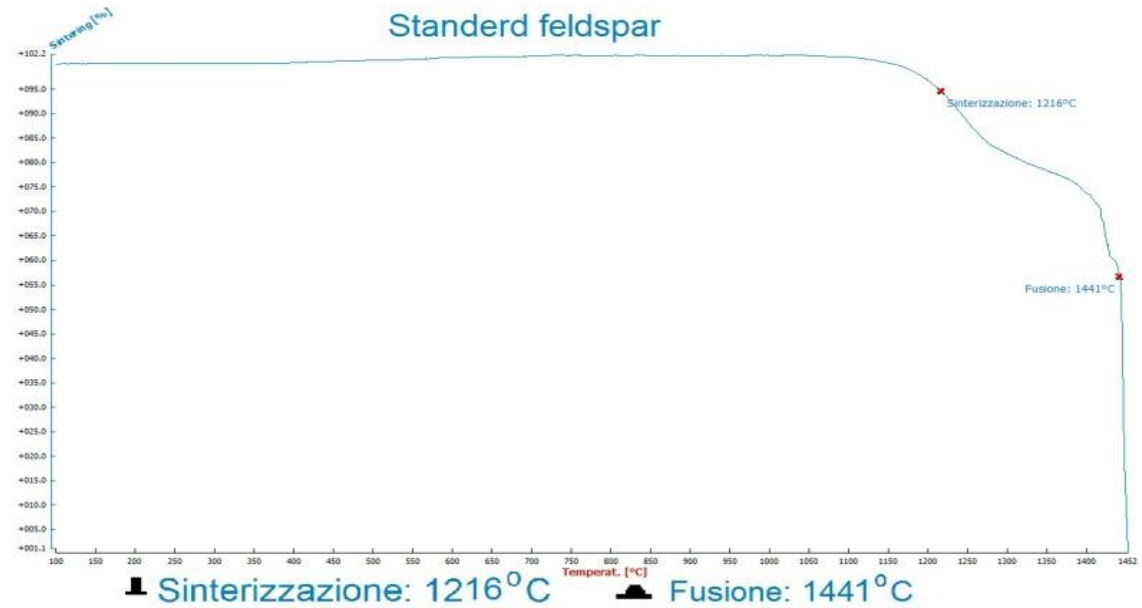

Fig (23): Ignition curve of the standard feldspar of the Ceramica Cleopatra Company milting point

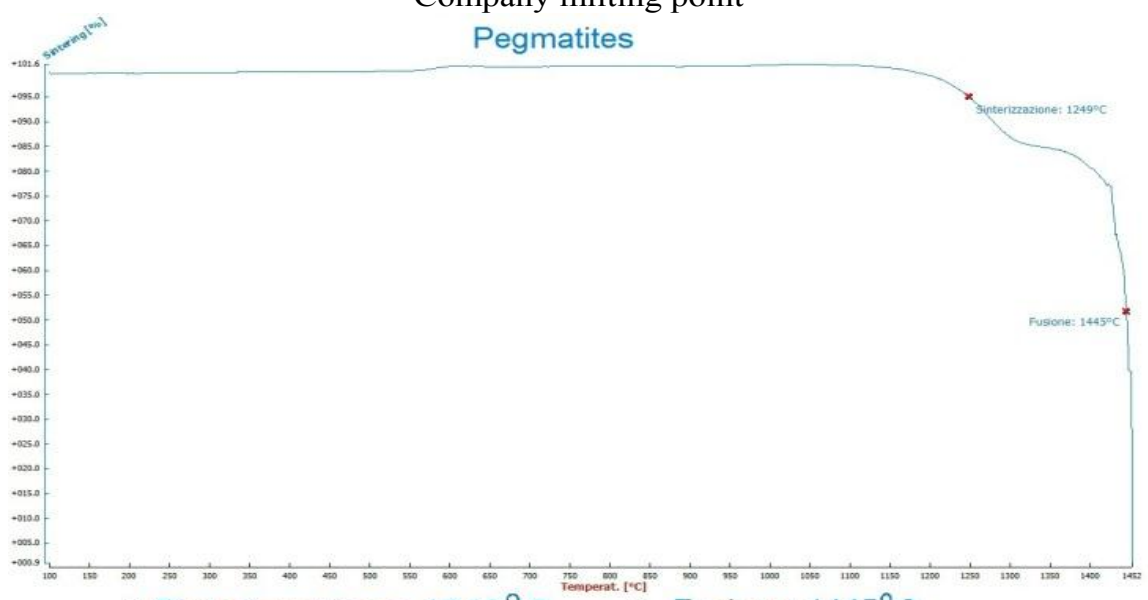

1 Sinterizzazione: $1249^{\circ} \mathrm{C}$

e. Fusione: $1445^{\circ} \mathrm{C}$

Fig (24): Ignition curve of the studied pegmatites melting point
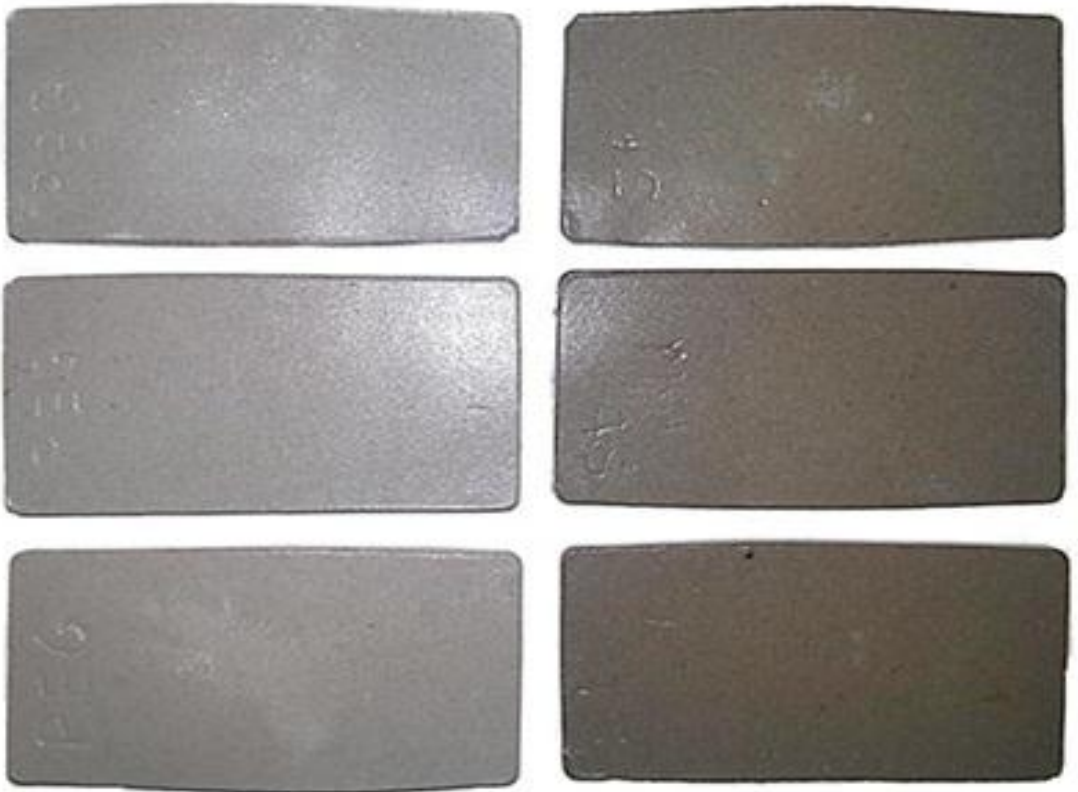

Abu Sheih pegmatites

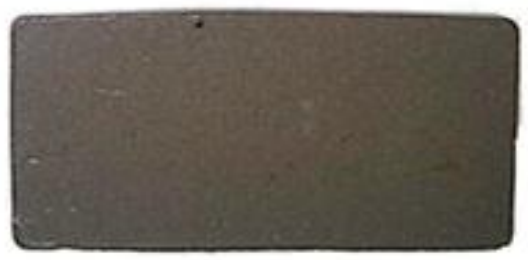

Standard feldspar

Fig. (25): Photograph showing the light color of fired samples of 


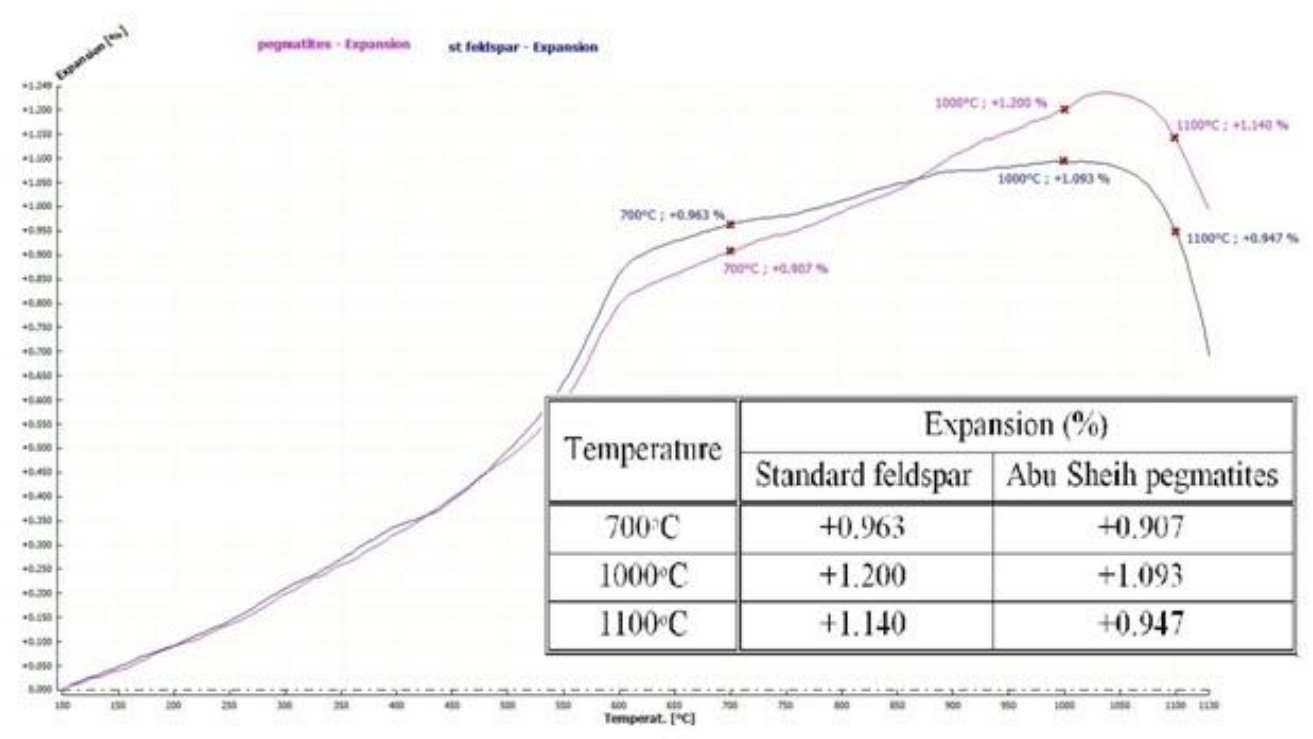

Fig 126): Thermal expansion of standard feldspar of the Ceramica Cleopatra Company and studied pegmatites

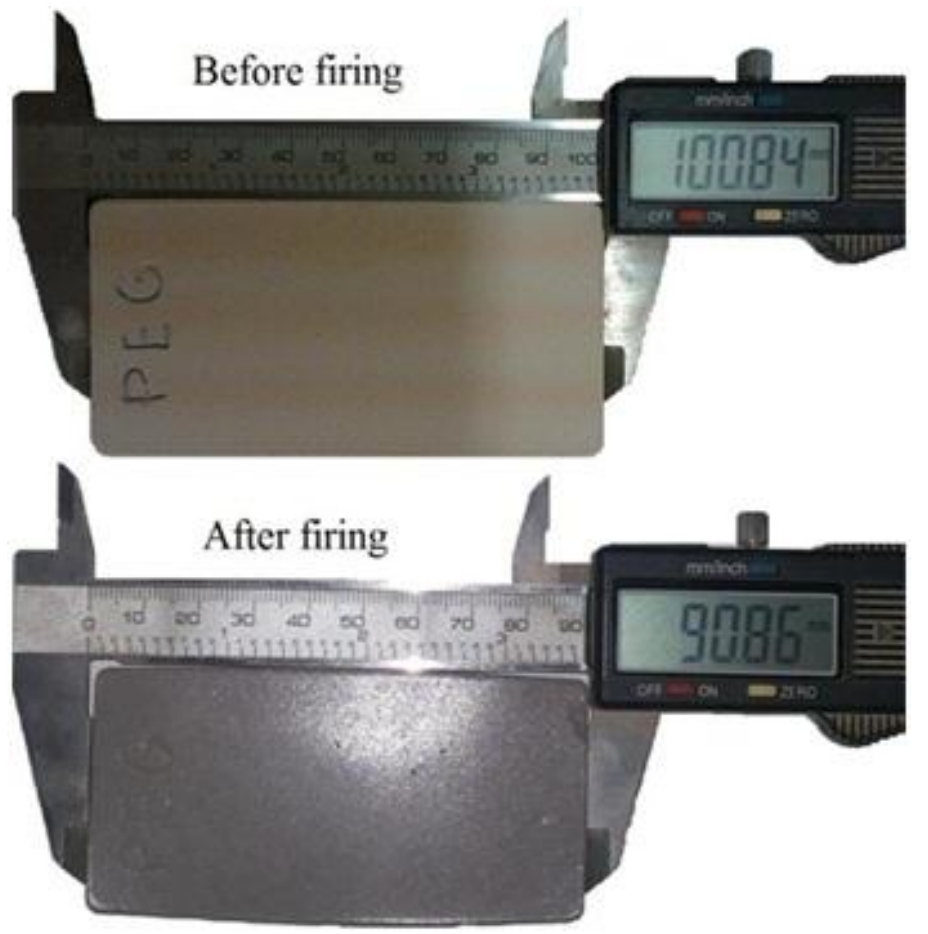

Fig 127: Shrinking before and after firing of Abu Sheih pegmatites

6.3.3. Shrinkage, water absorption and bending strength

After firing at $1220^{\circ} \mathrm{C}$, the shrinkage and bending strength of Abu Sheih pegmatites show little increase, while water absorption decreases (Table 7 and Fig. 34). This indicates that, the physical properties of Abu Sheih pegmatites are more or less near the standard feldspar.

\section{CONCLUSIONS}

From the field relationships and observations the pegmatites occur as small stock like body invading the surrounded granodiorites and syenograniteswith sharp contact. They consist mainly of K-feldspar and quartz present in the core. They are characterized by their high silica contents with an average value of $70 \%$, potash contents with an average value of $7 \%$ lower con- 
tent of trace element and high contentes of $\mathrm{Rb}$ and Y.The average of $U$ and $T h$ in pegmatites is lower than $\mathrm{U}$ and $\mathrm{Th}$ of world uraniferouspegmatites (Ford 1982) and Egyptian uraniferous pegmatites after (Heikal et al. 2001).

These studes have shown that pegmatites may be used advantageously as replacements for high potash feldspars with little or no significant changes in the fired properties of ceramic tiles industries.

\section{REFERENCES}

Abbady, A.G.E., Uosif, M.A.M. and EL-Taher, A. (2005): Natural radioactivity and dose assessment for phosphate rocks from Wadi El-Mashash and El-Mahamid Mines, Egypt. Journal of Environmental Radioactivity 84, 65-78. (2005).

Abdelrahman, M. E. H. (2014): The application of Thermal Remote Sensing Imagery for studying uranium mineralization: A new exploratory approach for developing the radioactive potentiality at El-Missikat and El-Eridiya district, Central Eastern Desert, Egypt. Ph.D. Thesis, Fac. Sci, Damietta Univ., Egypt, 287p.

Aboelkhair, H., Ninomiya, Y., Watanabe, Y., Sato, I.,( 2010): Processing and interpretation of ASTER TIR data for mapping of rare-metal-enriched albitegranitoids in the Central Eastern Desert of Egypt. Journal of African Earth Sciences 58, 141-151.

Assran, A.M. (2002): Application of ground magnetic and multi frequency EM techniques for Abu-Shihat radioactive prospect area, North Eastern Desert, Egypt. J ApplGeophsics, Cairo, Egypt, v.1 , p.157-170.

Azab, F. A. M. (2011): Petrographical, mineralogical and geochemical studies on WadiSafaga granites to the north of G. Um El-Huwitat, Eastern Desert, Egypt.M.Sc. Thesis, Fac. Sci, Menoufia Univ., Egypt.

Barker, F. (1979): Trondhjemite definition, environment and hypothesis of origin. El Sevier, Amsterdam, pp. $1-12$.

Bishta, A.Z. (1999): Gamma-Ray spectrometry in relation to the petrology, tectonics and mineralization of later Proterozoic rocks between latitudes 26o 15' - 26o 40' and longitudes 33o 15' - 33o 50' E. Ph. D., Cairo Univ., p. 184.

Budnikov P. P. and Gevorkyan, Kh. O. (1952): Theory ofthe Formation of a Porcelain Body. Jour. Applied Chem.U.S.S.R., 24, p. 141, Chem., pp. 41-89.

Condie, K. C. (1973): Archeanmagmatism and crustal thickening . Geol. Soc. Amer. Bull., V. 84, pp 2981299.

EC (European Commission), (1999): Radiation protection 112. Radiological protection principles concerning the natural radioactivity of building materials.Directorate-
General Environment, Nuclear Safety and Civil Protection.

El-Naggar, W.E. and Abdel-shafy, A.A. (2006): Examination of two granites phases along wadi Abu Zawal area, North Eastern Desert, Egypt. Delta J Sci, 2006, v.30, p. $149-164$.

El- Shazly, E. M., El- Kassas, I. A., and El- Tahir, M. A. (1982): Distribution and orientation of mafic dykes in Wadi Abu Zawal area, Eastern Desert, Egypt. Jour. Geol., v. 26, no. 2, p. 95-105.

El Reedy, M.W. (1984):The General Physical and Chemical Features and the Pollution Level ofElSabahia-Sabhan-El Reqa Soil Localities, State of Kuwait, Report represented to EnvironmentalProtection Dept. Ministry of Public Health, El Kuwait (Part I: ChemicalMethods).

El Tahir, M.A. (1978): Relation between geology and radioactivity of some basement rocks to the north of Qena- Safaga asphaltic road, Eastern Desert, Egypt, M.Sc. Thesis, Al Azhar University, Cairo, Egypt (unpublished).

Ford K.L. (1982):Uraniferous pegmatites of the Sharbot Lake area, Ontario.InMaurice Y.T. Uranium in Granites [M]. pp.81-23, 125-138.Geol. Surv. of Canada.

Habib, M.S. (1982): Landsat investigation of mineralized granites in the area between G. El-Urf and G. El-Erediya, west Safaga, Egypt. Proc. 8th Inter. Symp.Burchue Univ., 15.

Heikal, M.T.S., Moharem, A.F. and El-Nashar, E.R. (2001) :Petrogenesis and radioactive inspection of Li-mica pegmatites at WadiZareib, central Eastern Desert, Egypt, The Second International Conference on the Geology of Africa, Assiut, Oct. 2001, II: 227-305.

Hine, R.H., Williams, I.S., Chappell, B.W. and White, J.R. (1978): Geochemical contrast between I-and S-type granitoidsof the Kosciusko Batholiths. J. Geol. Soc. Assiut. 25, 219 - 234.

Irvin, T.N. and Baragar, W.R.A. (1971): A guide to the chemical classification of the common volcanic rocks. Canada. J. Earth Sci., vol. 8, pp. 523-548.

Konta, J. (1979): Ceramic Monographs, Handbook of Ceramics, VerlagSchmidGmb, H Freiburg, pp: 800.

Moussa, and Abu El leil,I. (1983): Structural analysis as aguide to mineralization trends in the north Eastern Desert of Egypt. Ann Geol. Surv. Egypt. V. XIII, p.271-267.

O'connor, J. T. (1965): A classification of quartz - rich igneous rocks based on feldspar ratios. U.S. Geol. Surv. prof. pap. 258, pp.79-84.

Read, H. H. (1984): Rutley's elements of mineralogy. Published by S. K. Jain for CBS Publishers and Distributors, Delhi, India, $560 \mathrm{P}$. 
Rogers, J.J.W., Adams, J.A.S. (1969): Handbook of Geochemistry: ed. K. H. Wedepohl, II/4 Springer-Verlag, P. 90 A-0.

Shapiro, L. and Brannock, W. W. (1962): Rapid analysis of silicate, carbonate and phosphate rocks.U.S. Geol. Surv. Bull. 1144A, 56 P.

Sharara, N. A., Abu El-Ela, F., El-Nady, O. M. and Soliman, M. F. (1990): Geology and geochemistry of the island arc association of the area around Gabal El-Urf, Eastern Desert, Egypt. Bull. Fac. Sci., Assiut Univ., v. 19, np 1-F, p. 97-122.
Soliman, M.F. (1988): Geologic studies on the basement complex of El-Urf area, Eastern Desert, Egypt. M. Sc. Thesis, Fac. Sci., Assiut Univ., Egypt, 112p.

Streckeisen, A. (1976): To each plutonic rock its proper name. Earth Sci. Rev., V. 12, pp. 1 - 33.

Tzortzis, M., Tseetos, H. Christofides, S. and Christodoulides. G. (2003): Gamma radiation measurements and dose rates in commercially-used natural tilling rocks (Granites). J. Environ. Radioact. 70:223-235.

UNSCEAR, (2000): Sources and effects of ionizing radiation. Report to General Assembly, with Scientific Annexes, United Nations, New York. 